\title{
A multiple scale, function, and type approach to determine and improve Green Infrastructure of urban watersheds
}

\author{
Nils Arthur ${ }^{\mathrm{a}}$, Jochen Hack ${ }^{\mathrm{b}, *}$

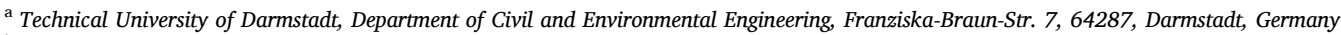 \\ b Technical University of Darmstadt, Institute of Applied Geosciences, Section of Ecological Engineering, Research Group SEE-URBAN-WATER, Schnittspahnstr. 9, \\ 64287, Darmstadt, Germany
}

\section{A R T I C L E I N F O}

\section{Handling Editor: Ian Mell}

\section{Keywords:}

FRAGSTATS

Green Infrastructure

Landscape metrics

Nature-based solutions

Spatial analysis

Urban ecology

\begin{abstract}
A B S T R A C T
Green Infrastructure (GI) connects different types of green features via various scales, thereby supporting urban biodiversity and service provision. This study presents a methodology capable of identifying multiple functions to assess GI in less-developed countries, where such methodologies are lacking. GI was assessed based on a highresolution land use classification using both landscape metrics and spatial data within an urbanized region of San José, Costa Rica, at different scales (watershed, neighbourhood, object). Results showed highly fragmented green spaces (often $<10$ ha), typically unable to support high levels of biodiversity, along with a low amount of green space per inhabitant $\left(<7.4 \mathrm{~m}^{2}\right)$ within the watershed. Substantially higher tree cover $(\mathrm{x} 6)$ and tree density (x5) were found in the greenest neighbourhood in comparison to the least green neighbourhood. Potential areas for new GI in the form of green roofs (4.03 ha), permeable pavement (27.3), and potential retention areas (85.3) were determined. Several green spaces $(n=11)$ were identified as promising GI sites with the potential to increase provision ( $18.6 \mathrm{~m}^{2}$ /inhabitant). The adopted methodology demonstrates the potential of GI for increasing recreational green space access, runoff reduction, and flood retentions while supporting biodiversity, validating its utility in guiding decision-making and policy generation.
\end{abstract}

\section{Introduction}

One of the main sustainability challenges of the future is dealing with the consequences of increasing urbanization (United Nations, 2019). Dealing with this challenge requires not only the provision of necessary grey infrastructures in form of housing, transportation, industrial areas, and supply systems, but also addressing both public health (e.g., air and water pollution, flooding, noise, heat islands) and environmental issues (e.g., fragmentation and degradation of ecosystems, biodiversity loss) amplified through climatic changes (Margulis, 2016; Taubenböck et al., 2015). The concept of Green Infrastructure (GI) is considered a promising approach to address these negative effects of urbanization and climate change (European Commission, 2013). The aim of GI is to protect and enhance nature by consciously integrating natural processes into spatial planning and territorial development, thereby providing benefits such as stormwater regulation or recreation, and at the same time supporting biodiversity. GI can be understood as a strategically planned network of natural and semi-natural areas with other environmental features designed and managed to deliver a wide range of ecosystem services (European Commission, 2013).

Initially developed in the USA and related to Low Impact Development (LID; Fletcher et al., 2015), GI is increasingly being implemented by various countries and political entities. The European Union has adopted and integrated GI in various planning processes (European Commission, 2013). Both China and Australia have adopted country-wide GI concepts in sustainable water management in urban areas, through the Sponge City (Chan et al., 2018) and Water Sensitive Urban Design (WSUD; Roy et al., 2008) projects respectively. However, in other parts of the world, GI has not been widely adopted (e.g. Latin America, see Vásquez et al., 2019). This low adoption rate is partially due to a lack of policies and practical guidelines for implementing GI within those parts of the world (Dobbs et al., 2019; Vásquez et al., 2016). In particular, there is a lack of methodologies for evaluating and improving GI in urban areas. The term Urban Green Infrastructure (UGI) has been established in scientific literature and often refers to urban stromwater management (e.g., Green Stormwater Management; EPA, 2021) or climate adaptation of cities (Gill et al., 2007), thereby dealing with major urban challenges. In this context, permeable or vegetated

\footnotetext{
* Corresponding author.

E-mail addresses: nils.arthur@stud.tu-darmstadt.de (N. Arthur), hack@geo.tu-darmstadt.de (J. Hack).
} 


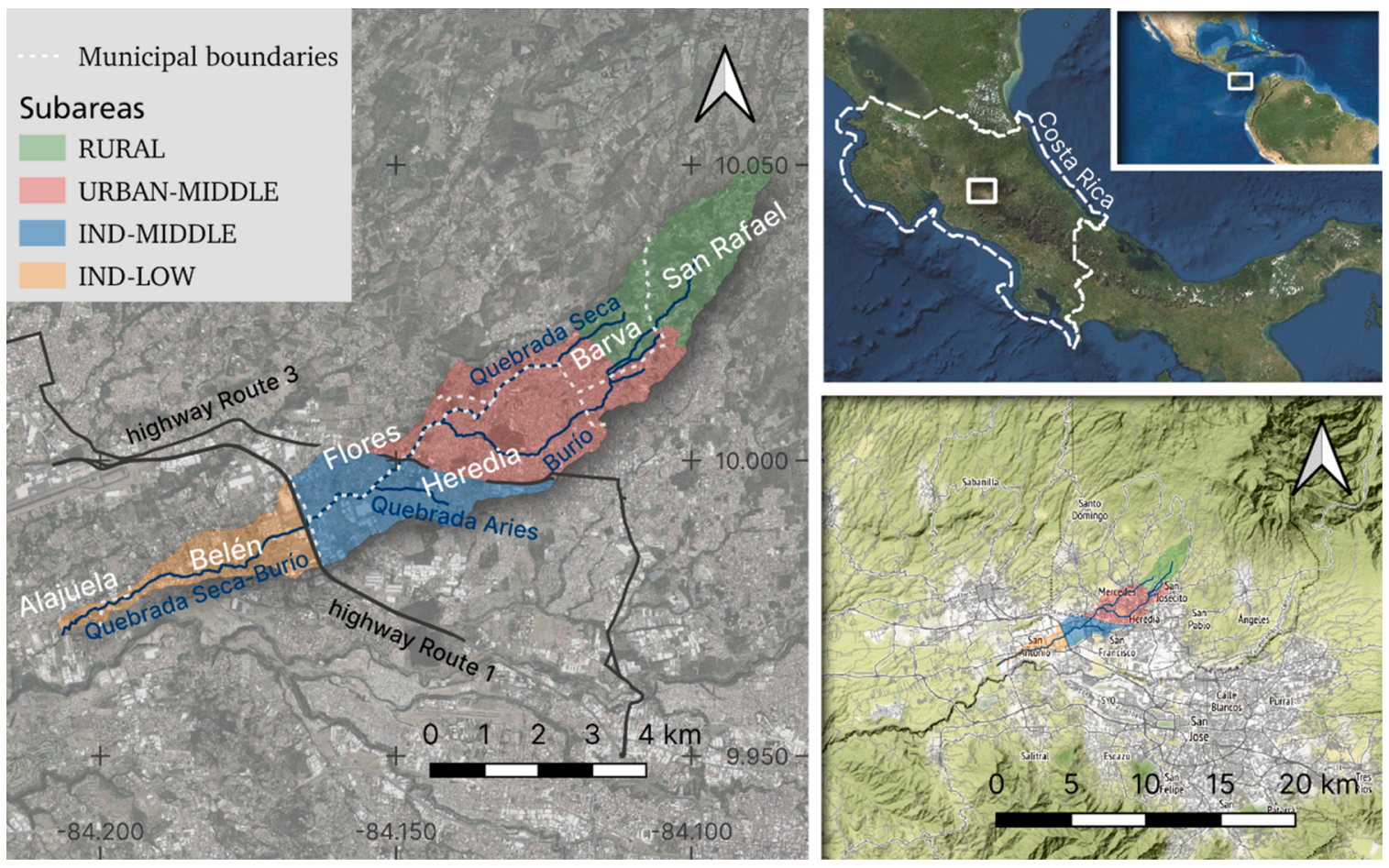

Fig. 1. Location of Costa Rica (top left), Greater Metropolitan Area (bottom left) and Quebrada Seca-Burío watershed including subareas and highways (right).

surfaces, green roofs, public parks, green walls and roofs, urban forests, green alleys and streets, community gardens and urban wetlands are commonly described as UGI elements (Gill et al., 2007), but also Sustainable Drainage systems (SuDS) can be considered as elements of UGI (Van Oijstaeijen et al., 2020). The implementation of UGI into practice remains slow (Dhakal and Chevalier, 2017), despite recent growing academic interest. In this paper, we use the term Green Infrastructure (GI) considering GI in the proximity of cities as well as UGI without referring to it as such explicitly. Since urban areas in less developed countries are often characterized by insufficient service infrastructure (e.g., for storm and waste water treatment) as well as consisting of few recreational and climate regulating green spaces, it is expected that substantial improvement could be achieved via GI implementation (Albert et al., 2021; Hack and Schröter, 2021). Concerning biodiversity support, rivers and their corridors in urban areas play an important role as biological corridors and often as the last remaining connected green spaces of the urban landscape (Hack et al., 2020; Hack and Schröter, 2021).

This study presents a methodology consisting of multiple scales, tools, and indicators to identify multiple functions to assist and guide the assessment of existing green infrastructures and the strategical planning of GI improvements of multiple types in already developed urban areas. The assessment of existing green infrastructures is based on a high spatial resolution land use classification and a calculation of landscape metrics related to the spatial distribution, fragmentation, and connectivity of green spaces, in particular focusing on the functionalities and accessibility of public green spaces. Besides public green spaces, the potential for green roofs, permeable pavement, roadside greenery characteristics of different neighbourhoods, and water retention functions along river corridors are assessed as important elements of the GI network as well. The deficiencies and potential of the existing GI network are then addressed with recommendations for improving future GI implementation.

The Quebrada Seca-Burío watershed, located in the Greater Metropolitan Area of Costa Rica's capital San José, is used as a study area for GI assessment and the development of proposals for improvement. In Costa Rica, almost $80 \%$ of the population are living in urban areas
(United Nations, 2019), most of them in the Metropolitan Area of the country's capital San José in the central valley. This degree of urbanization is typical for the region as well as the concentration of populations in large metropolitan areas. Although still advancing, most of the urbanization in Costa Rica has taken place during the 1980s and early 2000s (Masís-Campos and Vargas Picado, 2014), often in an uncoordinated and partly informal manner. This has led to urban development with priorities on housing and transportation at the cost of green spaces and natural areas (Pérez Rubi and Hack, 2021). The case study is used to illustrate the methodology of GI assessment for already consolidated urban areas, to highlight deficiencies in existing GI, and to provide practical guidance for strategic improvements based on the prevailing characteristics, constraints, and opportunities of the particular area of investigation. Although the application of the methodology is exemplified for the case study, it is generalizable and can be applied in other countries where practical guidance on GI assessment and strategical planning is underdeveloped.

\section{Materials and methods}

\subsection{Study area}

The Quebrada Seca-Burío watershed consists of a total area of $23 \mathrm{~km}^{2}$ and is located in the Greater Metropolitan Area of Costa Rica's capital San José (Fig. 1). The river courses of the watershed (Quebrada Seca, Río Burío, and Quebrada Aries) flow in East-West direction through the six cantons (municipalities) of San Rafael, Barva, Flores, Heredia, and Belén in the province of Heredia. The lower course is in the province of Alajuela, where it flows into the Río Pirro. The watershed forms part of the Río Grande de Tárcoles River Basin, which flows into the Pacific Ocean on Costa Rica's west coast. The Tárcoles River Basin receives water from almost the entire Greater Metropolitan Area and represents the most urbanized river basin in the region. The highest point of the watershed is at 1617.5 m.a.s.l., and the area outlet is at 861.8 m.a.s.l. The gradient of the river bed oscillates between 4-8\% (Oreamuno and Villalobos, 2015). The tropical climate of the region is characterized by a defined dry period from December to April. During the rainy season, May to 


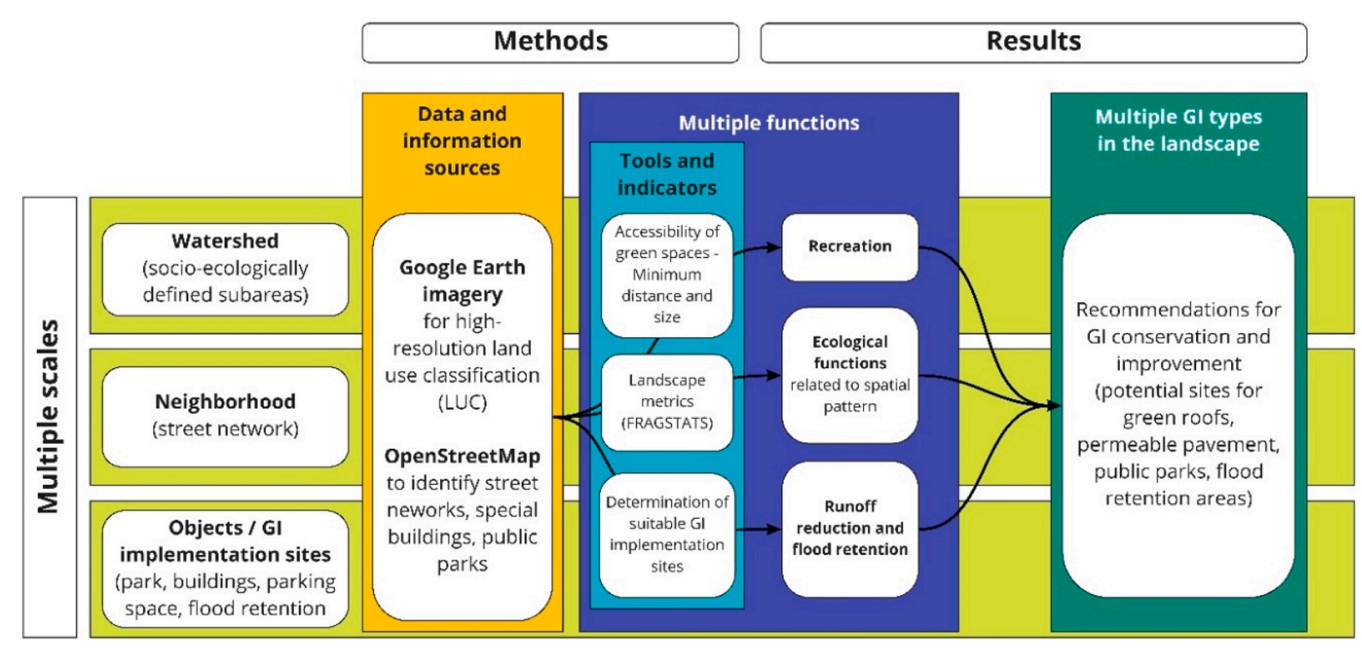

Fig. 2. Methodological approach based on multiple scales, functions and types of Green Infrastructure and the data and methods used.

November, heavy rainfall is common. The average annual precipitation is $1850 \mathrm{~mm}-2400 \mathrm{~mm}$ (Masís-Campos and Vargas Picado, 2014). In the Metropolitan Area, $90 \%$ of natural disasters are hydro-meteorological in origin, with floods $(60 \%)$ and landslides (30\%) being the most frequent type of disasters (Quesada-Román et al., 2021). Rainfall intensity, topography, population density, and degree of sealing in the watershed lead to frequent flooding during the rainy season (Chapa et al., 2020; Singh et al., 2020; Towsif Khan et al., 2020). The watershed has a total population of 115,776 inhabitants with an average population density of 4160 inhabitants per $\mathrm{km}^{2}$, with almost $50 \%$ living in the canton of Heredia (Masís-Campos et al., 2020).

The watershed was divided into four subareas for two reasons. Firstly, the division of the watershed is intended to enable more accurate comparison between different parts of the watershed. Secondly, it is necessary to divide the watershed, as the calculation of landscape metrics is limited to data up to a certain size. The watershed is characterized by two highly trafficked highways, (i) the Ruta 1 General Cañas highway at the border of the Belén and Flores cantons and (ii) the Ruta 3 highway and in the upper part of the watershed at the transition of the densely urbanized area to a predominantly rural part of the watershed (Fig. 1). These highways represent significant ecological and social barriers and are therefore used to divide the watershed area into four socio-ecologically coherent subareas as the basis for further analysis:

1 Industrial-urban lower reach (IND-LOW) in Alajuela and Belén.

2 Industrial-urban middle reach (IND-MIDDLE) in Flores and Heredia.

3 Highly urbanized middle reach (URBAN-MIDDLE) in Heredia,

Flores, Brava, and San Rafael.

4 Rural headwaters (RURAL) in Brava and San Rafael.

To evaluate the accessibility of green spaces, areas within the perimeter of the watershed are also taken into account since accessibility is not limited by the hydrological watershed boundaries.

\subsection{Methods}

The methodological approach adopted in this study consisted of multiple scales, functions, and GI types (Fig. 2). Multiple scales were considered to take different socio-ecological contexts of GI functioning as well as different GI types into account. The largest spatial scale represents the entire study area, the Quebrada Seca-Burío watershed and its four subareas (Fig. 1). In consideration of the highly urbanized state of the watershed, the streets space of residential neighbourhoods with different settlement characteristics was chosen as the next smaller scale to specifically assess green infrastructure in public (street) space. And finally, the object level representing the particular potential for green infrastructure of the built environment (buildings, parking lots) and public green spaces (undeveloped areas, parks) was chosen as a third scale. While the subareas of the watershed and the street space were used to determine the existing GI potential and deficits, the object scale was used to identify potential sites for new GI. The river corridor, due to being the only large-scale ecologically connecting feature of the study area and its capacity for flood retention, was considered across all three spatial scales, as a feature of the existing GI and for the identification of potential sites for new GI.

The methodological approach was assessed using a high spatial resolution land use classification (LUC) and landmark information retrieved from Open Street Map (OSM) as principal data and information sources (Fig. 2). Landscape metrics, the determination of suitable GI implementation sites, and accessibility of green spaces were applied to assess and improve the multiple social, ecological, and hydrological functions of green infrastructure at the different spatial scales. In a final step, recommendations for GI conservation and improvement through multiple types of GI taking into account multiple scales and multiple functions were developed.

\subsubsection{Mutiple scales}

The benefits of individual GI elements often arise only in their interaction with each other and through their spatial interconnectedness (Schwarz et al., 2017). Thus in addition to local site conditions (here object scale), consideration of the landscape scale (here watershed and its subareas) is equally important for GI assessment and planning. Therefore, multiple spatial scales have to be considered to assess and develop GI. In this study, we considered the landscape scale with socio-ecologically defined subareas of the watershed including the river corridor and the local scale with street networks of selected neighbourhoods as characteristic urban areas. For both scales, the assessment of metrics of connectivity and fragmentation is carried out to reveal spatial pattern related functionalities and GI characteristics. Furthermore, the object scale is considered with punctual, linear, or large-scale objects, such as retention areas along the river corridor, roadside greening or parks complementing the GI network. This object scale is used for the identification of potential sites for GI implementation at the property level, in road systems, and in open space, as well as for the assessment of the provision of recreational functions of larger public green spaces.

\subsubsection{Data and information sources}

For the land use classification (LUC), the open-source Semi-Automatic Classification Plugin (SCP, Version 7.2.6; Congredo, 2020) in the 
Geoinformation System QGIS (Version 3.12; QGIS Project, 2018) was used. The input data were true colour satellite images from Google Earth (Gorelick et al., 2017) of high spatial resolution. A resolution of $0.3 \mathrm{~m}$ was chosen to detect even small elements such as single trees and bushes (Chapa et al., 2019; Tran et al., 2011). The supervised land use classification follows the approach proposed by Chapa et al. (2019). The use of Google Earth images for LUC has been recommended as a reliable and valid source of information for urban applications (Malarvizhi et al., 2016). The satellite images were obtained with the software Google Maps Downloader (Allmapsoft, 2021). 21,182 single images (date of acquisition: January 6, 2020, date of download: May 7, 2020, provided by Maxar Technologies, CNES/Airbus) were downloaded at the highest available zoom-level (20 of 21) for the observed region and merged into one high-resolution satellite image (spatial resolution $0.3 \mathrm{~m}$ ). Open access spatial data was collected from Open-Street-Maps (OSM; streets, parking lots, industrial and commercial buildings, public parks) and used to improve the results of the land use classification.

After dividing the watershed into subareas, the SCP plugin was applied to each subarea. In total, six classes were defined for the LUC: buildings, low vegetation, high vegetation, bare soil, pavement, and shadow. Due to the high resolution of the imagery, areas as training inputs could be visually assigned in varying amounts depending on the prevailing land use in the different subareas. In URBAN-MIDDLE 23 training areas were defined, 13 of them were buildings (IND-LOW 15 training areas, IND-MIDDLE 19, RURAL 24, 5 of them for the class high vegetation). The classification algorithm Maximum likelihood was chosen to perform the supervised classification as it yielded better results compared to the Minimum Distance and Spectral Angle algorithms.

For the LUC at the watershed scale, there were no training inputs for the class streets defined to avoid misclassification between streets and buildings (Chapa et al., 2019). The streets were obtained as shape files from OSM and added during the post-processing of the LUC. The added streets were $8 \mathrm{~m}$ wide. Adding streets and parking areas increased the accuracy of the land use classification and reduced the misclassification between buildings, pavement, and high vegetation. Industrial and commercial buildings available in OSM were added to the classification, too. The proportion of shadow could be reduced to $1-2 \%$ for the different subareas during post-processing. Primary classified shadow areas within high vegetation, like forests, were converted into high vegetation. Within urbanized areas, shadows were changed into the classes buildings or pavement. The overall accuracy of the LUC was calculated using the built-in accuracy assessment tool of the SCP-plugin by visually comparing 200 randomly selected pixels of the LUC with the classified high-resolution satellite images. This resulted in an overall accuracy across all land use classes of $89 \%$. Finally, the LUC was sieved to eliminate isolated pixels (threshold 8 pixels) and exported for further calculations in FRAGSTATS with a recalculated resolution of $0.5 \mathrm{~m}$. This step was carried out to reduce the data load.

For the LUC of the street network at the neighbourhood scale, the original resolution of $0.3 \mathrm{~m}$ of the LUC was maintained for all calculation steps. The OSM street network shape file was buffered with a width of 16 $\mathrm{m}$ and used as a mask for defining the road space. Since this analysis step focused on the identification and assessment of street greenery only, the selection of a buffer width of $16 \mathrm{~m}$ included street space and sidewalks while excluding backyards, green spaces, and vacant areas within the neighbourhoods. The number of training input was between 28 and 42 for each of the 8 selected neighbourhoods (N1: 42, N2: 33; N3: 40; N4: 38; N5: 34; N6-N8: 28) and predominantly was chosen for the classes pavement, high vegetation, and buildings.

\subsubsection{Tools and indicators to assess multiple functions of GI}

The GI of the watershed's subareas and its spatial distribution characteristics were analysed by the area proportions of the different land use types and the fragmentation and connectivity of vegetation patches. Additionally, high vegetation within the streets was assessed with landscape metrics. To calculate landscape and connectivity metrics, various parameters from the software FRAGSTATS 4.2 (McGarigal et al., 2012) were selected and related to the ecological functions of green spaces. Urban parks as public green spaces were examined by their accessibility described by distance and minimum size. The riparian corridor was analysed for suitable implementation sites for GI.

2.2.3.1. Calculation of landscape metrics related to fragmentation and connectivity of the existing GI. Landscape metrics were used in this study to relate spatial patterns of vegetation with ecological processes and functions (Turner, 1989) in an urban context (Ahern, 2007; Kim and Park, 2016). In particular, the fragmentation and the connectivity of urban green spaces were assessed. For the characterization of different neighbourhoods, six FRAGSTATS parameters were calculated. To measure the proportions of the different land use classes the Percentage of Landscape (PLAND) metric was calculated. In addition, the metrics Largest Patch Index (LPI), Number of Patches (NP), Patch Density (PD) and mean/ area-weighted mean (AREA_MN/AM), mean Euclidean Nearest Neighbor Distance (ENN_MN), Aggregation Index (AI) were used to assess the degree of fragmentation of the landscape (McGarigal et al., 2012). It was assumed that bigger and less fragmented (urban) landscapes bear higher biodiversity (Beninde et al., 2015), contribute greater to air quality (Grafius et al., 2018), heat island reduction (Bartesaghi Koc et al., 2018) and reduce peak runoff (Meerow and Newell, 2017). Beninde et al. (2015) recommended area-based thresholds for higher urban biodiversity, which were used for the multifunctional green infrastructure assessment of this study. According to Grafius et al. (2018), isolated patches were assumed to store less $\mathrm{CO}_{2}$ (Grafius et al., 2018). Ecological functions of green space were assigned to identified vegetation patches of varying size according to these assumptions.

FRAGTATS enables the calculation of functional connectivity based on land use characteristics, but the available connectivity parameters can also serve as indicators for the level of structural connectivity (Zhang et al., 2019). The parameters Effective Mesh Size (MESH) and Connectance Index (CONNECT) were calculated to take the intra- and inter-patch connectivity into account (Spanowicz and Jaeger, 2019).

Although the high-resolution land use classification applied in this study enables the detection of individual trees, low vegetation, like bushes, could not be identified with satisfactory accuracy on the streets and sidewalks when compared with information from field visits and Google Street View images. Thus, only high vegetation was considered for the landscape metric-based assessment of street networks. To assess and compare the characteristics of different neighbourhoods, areas of the same size (37 ha) were defined and the following six metrics were calculated: Total Class Area (CA), Patch Density (PD), Largest Patch Index (LPI), area-weighted mean Proximity Index (PROX_AM), areaweighted mean Euclidean Nearest Neighbor Distance (ENN_AM), and Aggregation Index (AI). For every neighbourhood, the ranking result of each parameter was added up to an overall rating and averaged (1-8).

2.2.3.2. Accessibility of public green spaces. For a quantitative statement about the provision of benefits of public green areas in cities, accessibility to the population is very important. Different recommendations regarding the maximum distance and minimum size of public green spaces to assure accessibility exist (Grunewald et al., 2016; Handley et al., 2003; WHO Regional Office for Europe, 2016). In this study, it was assumed that every resident should have a green space near their homes ( $300 \mathrm{~m}, 0.5 \mathrm{ha}$ ) and settlements (700 m, $10 \mathrm{ha}$ ) as studies from Latin America set the minimum park size at 0.5 ha, since parks in Latin American cities are often smaller than in Europe or the USA (Morales Cerdas et al., 2018; Reyes Päcke and Figueroa Aldunce, 2010; Wright Wendel et al., 2012). The availability of public parks per inhabitant $\left(\mathrm{m}^{2} / \mathrm{hab}\right)$ was used as an additional indicator to describe the public green space availability quantitatively. Based on the LUC, the classes low and high vegetation were merged to identify green patches larger 


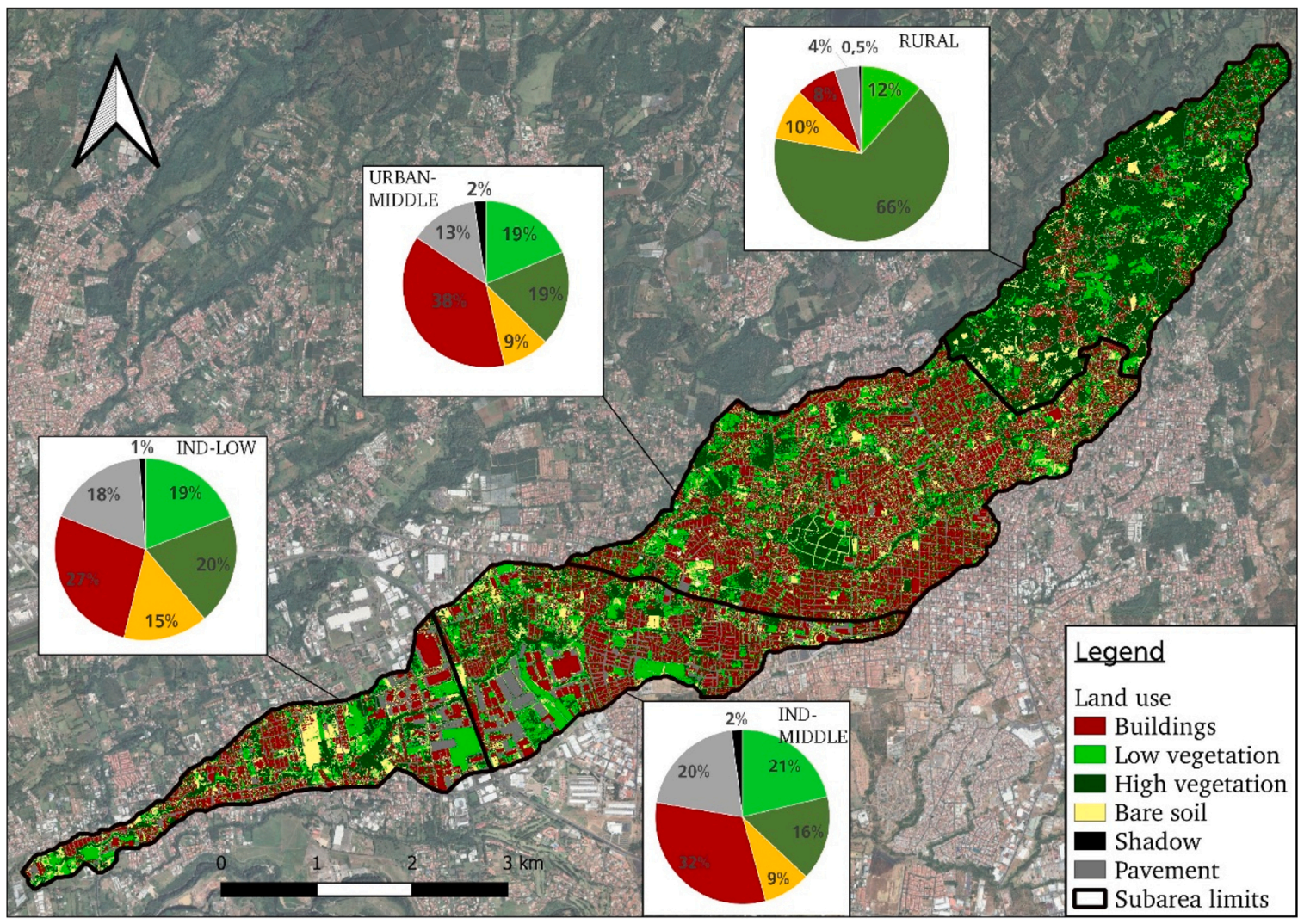

Fig. 3. Results of the land use classification for the four subareas.

than 0.5 ha. Then, the FRAGSTAT metric Fractal Dimension Index (FRAC) was calculated to identify all highly convoluted green patches (FRAC $>1,6$ ) to exclude them from further analysis since it was assumed that these areas were greenery on private land and between houses and not publicly accessible parks (Grafius et al., 2018). Next, the remaining patches were compared with the OSM data on public parks, playgrounds, and sport fields to declare them as publicly accessible or not. Vegetation in the rural parts of the study area was not taken into account and assumed as a whole as a publicly accessible green space. As a last step all areas identified as public parks, depending on their size, were buffered with $300 \mathrm{~m}$ (for areas between $0.5-10 \mathrm{ha}$ ) and $700 \mathrm{~m}$ (for areas $>10 \mathrm{ha}$ ) radius to determine their respective ranges of accessibility.

Using the population estimated by Masís-Campos et al. (2020), the quantity of public green space per inhabitant was calculated for every canton in the study area.

2.2.3.3. Determination of suitable implementation sites for GI at the object scale and along the river corridor. After the assessment at the watershed scale, the study focused on the identification of suitable sites for GI elements to improve the existing GI network. Sites were identified based on current land use. At object scale potential sites for additional public green spaces, flood retention areas, green roofs, and permeable pavement were quantified. Additionally, recommendations for the development of green corridors and improvements of street greenery were developed to increase the connectivity of green spaces.

The predominant residential building structures in the study area do not enable conversion to green roofs. Therefore, only flat roof areas of commercial and industrial buildings, larger hotels, and supermarkets were considered as potentially suitable for green roof conversion. Data from OSM and Google Earth imagery were used to identify these buildings.

To enable the assessment of potential flood retention areas, land use classes (high-low vegetation and bare soil) were merged. All areas connected, within $300 \mathrm{~m}$, to the river were considered as potential GI sites with retention function. These sites were manually identified after examining satellite images available from Google Earth. Areas with a high amount of high vegetation $(>10 \%)$ were not considered as potential flood retention areas. The areas of high vegetation in the riparian zone were only included in the analysis as a connecting element between the watercourse and the open spaces in order to define suitable sites of a minimum size. OSM data of parks and agricultural areas was used to prioritise multifunctional implementation sites. Larger parking lots were defined as potential temporal floodplains.

\subsubsection{Recommendations for multiple GI types in the landscape}

All potential GI implementation sites identified were assessed to develop specific recommendations for the four subareas. The key principles for the assessment were the multifunctional improvement potential and the reduction of areas with the highest socio-ecological deficit and flooding risk. The feasibility of the recommendations was taken into account by considering the current use of space as far as possible, e.g., a coffee plantation identified as vegetated areas was not further considered for turning into a new park. New public parks were recommended in areas where the population had no sufficient access and the flooding risk was higher according to Masís-Campos et al. (2020). The implementation of GI in existing green spaces was considered first because it was assumed that (i) their realisation is more viable and (ii) the effect of the multifunctional improvement is likely to be greater. In the highly urbanized middle reach (subarea URBAN-MIDDLE), ecological corridors were defined to ensure their preservation. Table A1 in the Annex summarizes how different functions of different types of GI were determined and recommendations for their improvement were derived. 
Table 1

Overview of the proportions of high, low, and total vegetation as well as vegetation patches $>1$ ha for each subarea.

\begin{tabular}{|c|c|c|c|c|c|}
\hline Subarea & Land use & $\begin{array}{c}\text { AREA_MN } \\
\left(\mathrm{m}^{2}\right)\end{array}$ & $\begin{array}{c}\text { AREA_AM } \\
\text { (ha) }\end{array}$ & $\begin{array}{c}\text { Proportion of } \\
\text { vegetation (\%) }\end{array}$ & $\begin{array}{c}\text { Patches }>1 \text { ha } \\
(\%)\end{array}$ \\
\hline \multirow{3}{*}{ IND-LOW } & Vegetation & 102 & 15.47 & 38.6 & \multirow{3}{*}{28.5} \\
\hline & high vegetation & 52 & 2.12 & 19.6 & \\
\hline & low vegetation & 29 & 2.56 & 19.0 & \\
\hline \multirow{3}{*}{ IND-MIDDLE } & Vegetation & 101 & 8.60 & 36.9 & \multirow{3}{*}{23.3} \\
\hline & high vegetation & 33 & 2.14 & 15.7 & \\
\hline & low vegetation & 29 & 1.31 & 21.2 & \\
\hline \multirow{3}{*}{ URBAN-MIDDLE } & Vegetation & 87 & 3.81 & 37.2 & \multirow{3}{*}{22.5} \\
\hline & high vegetation & 30 & 1.71 & 18.6 & \\
\hline & low vegetation & 22 & 0.40 & 18.6 & \\
\hline \multirow{3}{*}{ RURAL } & Vegetation & 462 & 67.60 & 77.7 & \multirow{3}{*}{74.5} \\
\hline & high vegetation & 264 & 44.19 & 66.1 & \\
\hline & low vegetation & 20 & 0.50 & 11.6 & \\
\hline
\end{tabular}

\section{Results}

Results are presented according to the different spatial scales. Recommendations for the conservation and improvement of GI are also presented.

\subsection{Watershed and subarea scale}

The results of the land use classification are shown in Fig. 3. All land use classes are present in all subareas, but there are significant differences in relative distributions of land uses. The proportions of building and pavement classes are high in the urbanized middle and lower parts of the watershed (IND-MIDDLE, URBAN-MIDDLE, IND-LOW). The highly urbanized middle reach (URBAN-MIDDLE) has the highest percentage of buildings (38\%). In the areas of the middle and lower reaches, which are partly characterized by both free trade and industrial zones, the proportion of paved surfaces is particularly high ( $20 \%$ and 18 $\%$ respectively). This can be attributed to the large parking lots of the industrial zones in these areas.

The sum of vegetation classes is below $40 \%$ in all three urban subareas. In the subarea IND-LOW, the percentage of unused land (bare soil) is higher (15\%) than in the other areas $(9-10 \%)$. The reason for this includes an approximately 9.8 ha construction site in the San Antonio district of Belén. The satellite images showed here the construction of new houses and streets. This also shows that the urbanization process in the watershed continues and a further increase in sealed surfaces can be expected.

In the upper part of the watershed (RURAL), over $3 / 4$ of the land is covered by vegetation (66 \% high vegetation, $12 \%$ low vegetation). Buildings and paved areas occupy only $12 \%$. There is an approximately equal distribution of low and high vegetation classes (circa 19\%) in the IND-LOW and URBAN-MIDDLE subareas. The highest level of low vegetation (21\%) is found in the IND-MIDDLE subarea.

When the two vegetation classes are combined into one class and only patches of 1 ha or greater are considered, the percentage of vegetated areas in all urban subareas reduces significantly. At least $10 \%$ of combined vegetation patches are smaller than 1 ha (Table 1 ). In the subarea URBAN-MIDDLE, where buildings are the predominant land use class, small vegetation areas are the most common (14.7\%). This indicates a greater fragmentation of the landscape in this part of the watershed. The average size of vegetation patches is particularly low in this part. The mean size of vegetation patches in subareas IND-LOW and IND-MIDDLE is approximately $100 \mathrm{~m}^{2}$, while the weighted mean of patches in IND-LOW is significantly higher (Table 1). This illustrates that few larger vegetation patches are found in IND-MIDDLE.

Only vegetation patches $>1$ ha were considered for the assessment of ecological fragmentation and connectivity within the watershed. Based on the findings of Beninde et al. (2015), five sizes of vegetation patches were related to ecological functions (Fig. 4): patches $<4.4$ ha with no particular ecological function (red), patches of 4.4-10 ha as potential habitats for urban adapters (orange), patches of 10-27 ha that additional bear higher $\mathrm{CO}_{2}$ storage (yellow), patches of $27-53$ ha that have potential to sustain higher urban biodiversity (light green), and finally patches $>53$ ha that are potential habitats for urban avoiders (dark

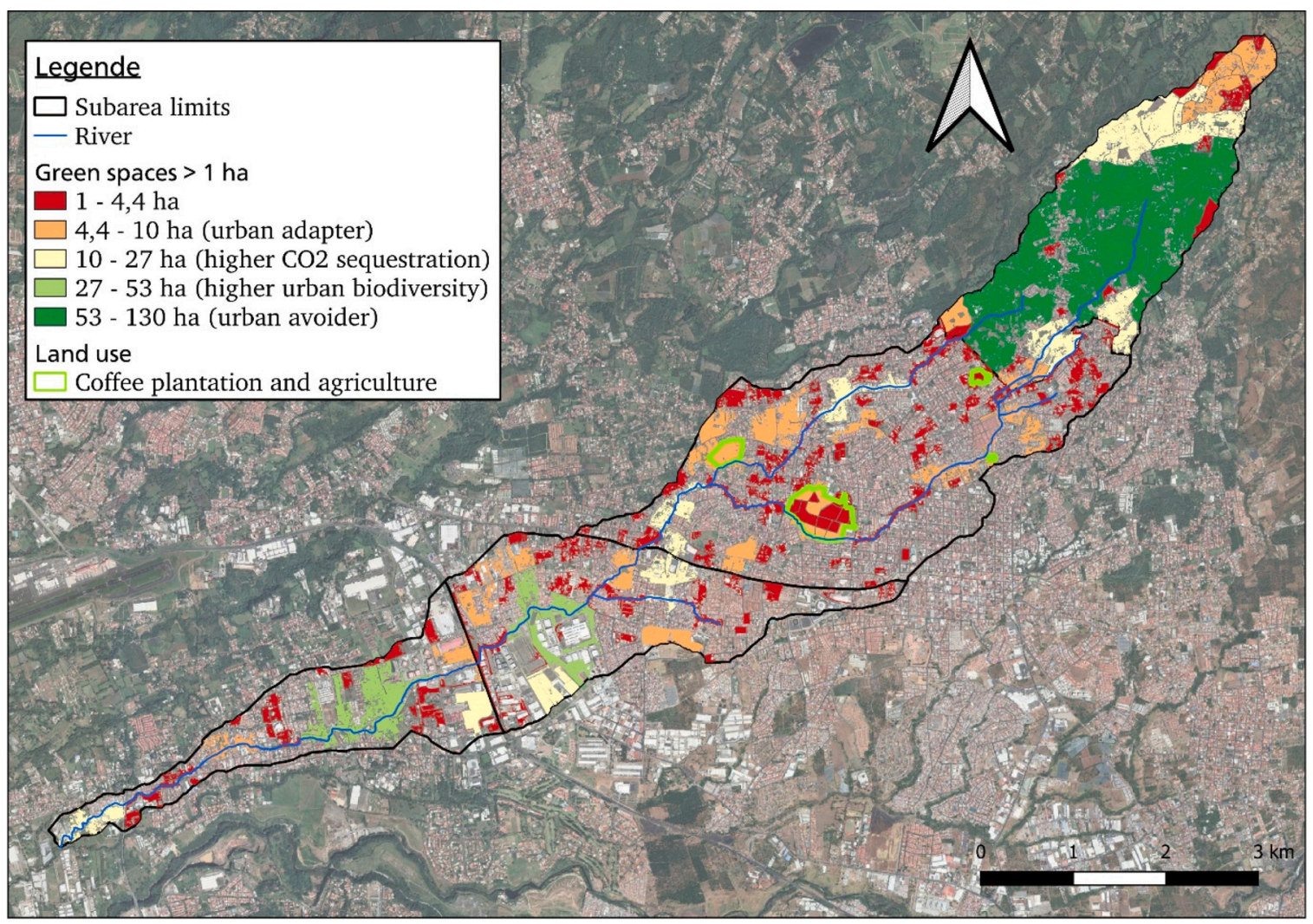

Fig. 4. Larger vegetation patches and associated ecological functions. 
Table 2

Landscape metrics calculated with FRAGSTATS for each subarea.

\begin{tabular}{|llrrrr|r|}
\hline Subarea & Land use & NP (-) & PD (1/100 ha) & LPI (\%) & AI (\%) & ENN_MN (m) \\
\hline IND-LOW & Vegetation & 13,577 & 3,807 & 11.7 & 95.1 & 1.76 \\
IND-LOW & Hohe vegetation & 13,344 & 3,742 & 2.6 & 92.0 & 2.20 \\
IND-LOW & Low vegetation & 23,666 & 6,636 & 2.9 & 88.7 & 1.72 \\
\hline IND-MIDDLE & Vegetation & 17,870 & 3,679 & 6.4 & 94.5 & 1.85 \\
IND-MIDDLE & Hohe vegetation & 23,043 & 4,744 & 2.3 & 89.5 & 2.21 \\
IND-MIDDLE & Low vegetation & 35,737 & 7,357 & 1.1 & 87.8 & 1.64 \\
\hline URBAN-MIDDLE Vegetation & 38,138 & 4,280 & 1.6 & 94.0 & 1.90 \\
URBAN-MIDDLE & Hohe vegetation & 54,699 & 6,139 & 0.8 & 89.8 & 1.95 \\
URBAN-MIDDLE & Low vegetation & 75,438 & 8,466 & 0.5 & 84.0 & \\
\hline RURAL & Vegetation & 9,403 & 1,681 & 23.3 & 97.9 & 1.68 \\
RURAL & Hohe vegetation & 13,988 & 2,500 & 16.2 & 96.4 & 1.44 \\
RURAL & Low vegetation & 33,178 & 5,930 & 0.6 & 86.0 & 1.63 \\
\hline
\end{tabular}

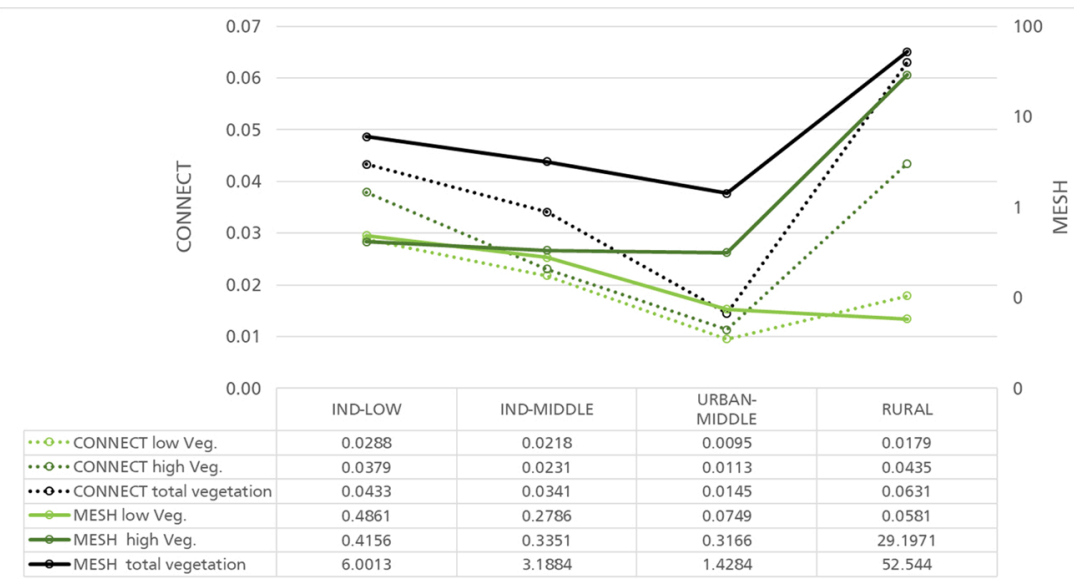

Fig. 5. Landscape metrics CONNECT (left y-axis) and MESH (right y-axis, log scale) for the four subareas.

green).

In the three urban subareas, 29 green spaces larger than 4.4 ha exist. Only two of these 29 vegetation patches are larger than 27 ha, located in the subareas IND-LOW (42.4 ha) and IND-MIDDLE (31.3 ha). Both of these larger vegetation patches comprise the river corridor as a connecting element, potentially providing both terrestrial and aquatic habitats. However, the large vegetation patch in the IND-MIDDLE subarea is significantly frayed with a small core area, limiting its potential positive effect on biodiversity. Additionally, the patch extends to large parts into industrial and residential areas.

The coffee plantation in the canton of Heredia in the URBANMIDDLE subarea (Fig. 4) is divided by a network of unpaved roads and was not analyzed as a contiguous green space. However, from an ecological or urban climatic perspective, it could be considered as one large green space. It has a vegetation area of 27.9 ha. All potentially suitable habitats for urban avoiders (vegetation patches $>53 \mathrm{ha}$ ) are located in the RURAL subarea of the upper part of the watershed. According to a study in the $\mathrm{UK}$, the capacity of $\mathrm{CO}_{2}$ sequestration increased most significantly up to an area of 10 ha (Grafius et al., 2018).

The FRAGSTATS parameters patch number (NP), patch density (PD), and the proportion of the largest contiguous patch (LPI or composite measure) were determined for a more detailed assessment of the degree of fragmentation of each subarea. Table 2 lists the FRAGSTATS parameter for the combined vegetation class and its subclasses, low and high vegetation. The number of patches (NP) is naturally lower in the smaller subareas. Together with the patch density (PD) and the values for the Largest Patch Index (LPI) it is possible to describe the fragmentation of the studied areas. The highly urbanized middle reach area (URBAN-MIDDLE) has the highest patch density in all vegetation classes and the values for LPI are very small. These are indications of a highly fragmented landscape with many small and unconnected vegetation patches. Thus, considering all FRAGSTATS values the URBAN-MIDDLE subarea is most fragmented while the RURAL subarea of the upper watershed is the least fragmented, with low vegetation found only scattered across the landscape (suggested by the relatively high ENN_MN value for low vegetation). ENN_MN results are very low overall.

Throughout the watershed, vegetation patches are less than $2 \mathrm{~m}$ apart. The mean distance between patches of high vegetation in the urbanized subareas is $1.95-2.21 \mathrm{~m}$, indicating a high level of connectivity. However, ENN_MN values provided limited information. The high spatial resolution of the LUC enables the detection of individual shrubs or small patches of grass, which results in a significant decrease in distances between vegetation patches. Nevertheless, the four subareas can be sorted in descending order using the ENN_MN for the combined vegetation class as follows: RURAL, IND-LOW, IND-MIDDLE, URBANMIDDLE. In the URBAN-MIDDLE subarea, the vegetation patches are on average the furthest apart.

The aggregation index (AI) measures spatial clustering within a class. The vegetation of the two subareas in the middle of the watershed is more dispersed than that in the RURAL and IND-LOW subareas. The low values of AI for low vegetation in the URBAN-MIDDLE confirm the high degree of fragmentation of this land use class. The cells coloured green in Table 2 indicate a better spatial distribution than the red cells (AI $<90$ $\%)$.

The CONNECT and MESH parameters are used to describe the connectivity of vegetation patches within the subareas. Overall, connectivity in the urbanized parts of the watershed is rated as low. The parameter MESH shows that only the vegetation in the RURAL subareas can be described as more connected. The other three subareas show very 


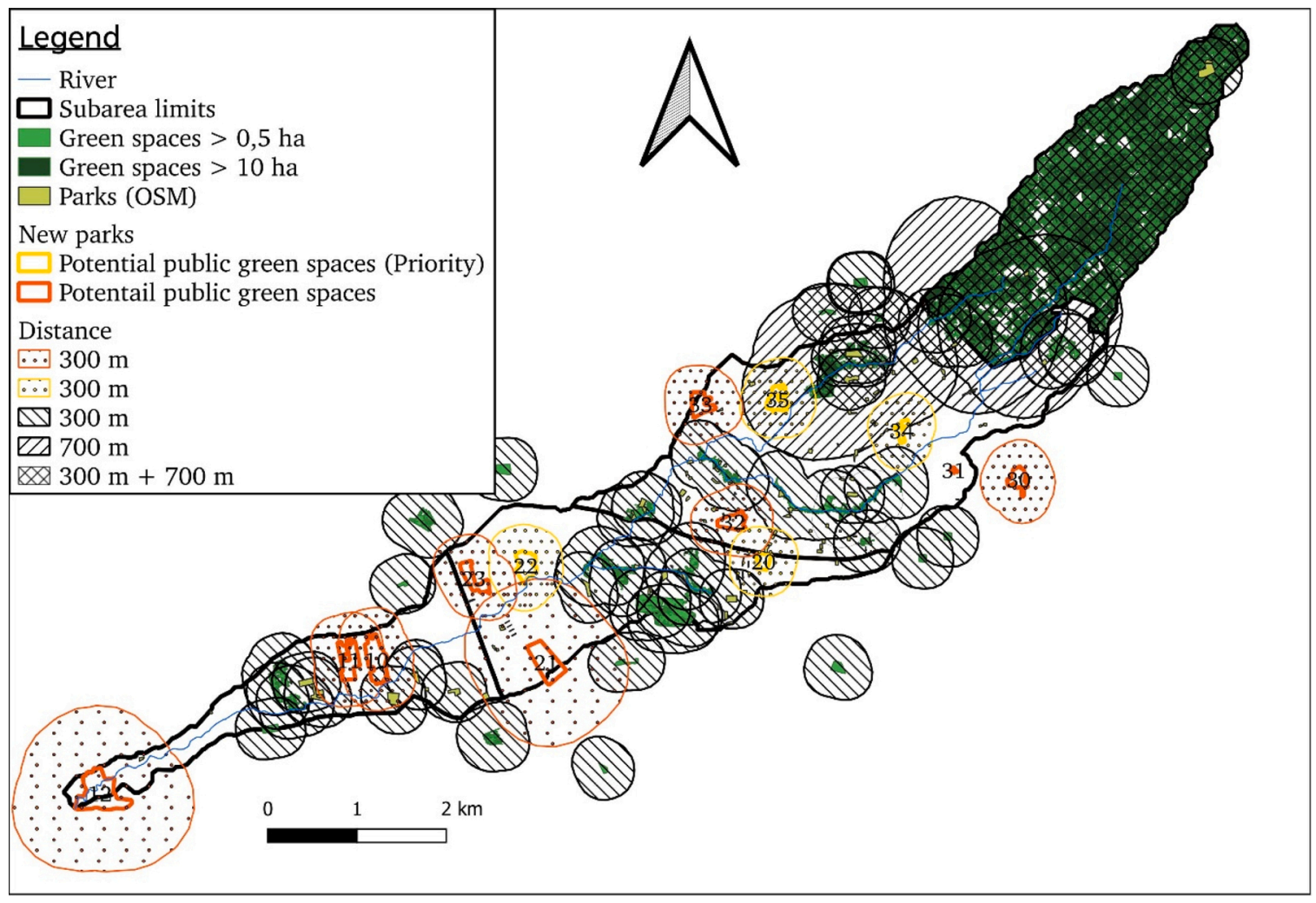

Fig. 6. Accessibility and distribution of existing and identified potential new public green spaces of $>5$ ha ( $300 \mathrm{~m}$ buffer) and $>10$ ha (700 $\mathrm{m}$ buffer) (For interpretation of the references to colour in this figure legend, the reader is referred to the web version of this article).

Table 3

Population, area, and public green space availability of each canton.

\begin{tabular}{lcccc}
\hline Canton & Inhabitants & $\begin{array}{l}\text { Area of } \\
\text { canton (ha) }\end{array}$ & $\begin{array}{l}\text { Public green } \\
\text { space (ha) }\end{array}$ & $\begin{array}{l}\text { Public green space per } \\
\text { inhabitant }\left(\mathrm{m}^{2} / \mathrm{hab} \text {.) }\right.\end{array}$ \\
\hline Alajuela & 2355 & 31 & - & - \\
Belén & 14,969 & 336 & 11.6 & 7.7 \\
Flores & 13,005 & 212 & 4.1 & 3.2 \\
Heredia & 55,207 & 822 & 40.7 & 7.4 \\
Barva & 11,813 & 365 & 14.6 & 108.4 \\
San & 18,427 & 521 & 311.3 & 171.4 \\
$\quad$ Rafael & & & & \\
\hline
\end{tabular}

weak connectivity. This is also suggested by the CONNECT results. However, differences can also be observed between the urban subareas. The connectivity in the URBAN-MIDDLE subarea is very low in all vegetation classes. Subarea IND-LOW achieves the best connectivity scores compared to the other urbanized areas. Fig. 5 shows the values and trajectories of the two connectivity parameters in the different subareas and for the combined and individual vegetation classes.

\subsubsection{Accessibility of public green spaces}

Public green spaces and parks are unevenly distributed throughout the watershed (Fig. 6). Populations from several areas must travel more than $300 \mathrm{~m}$ to benefit from parks or other public green spaces. Smaller public green spaces (0.5-10 ha) that could improve accessibility are too far away from the study area for inhabitants to travel. Within the urban subareas, there is only one public green space larger than 10 ha, which is located in the cantons of Brava and Heredia (URBAN-MIDDLE) and comprising the Quebrada Seca River corridor.

In terms of accessibility, the IND-LOW subarea is well-populated with public green spaces and parks in some areas, albeit some residents do not have green space available in their neighbourhoods. Several public green spaces are concentrated in the middle of the subarea, some of which also border the banks of the Quebrada Seca River. Public parks are within reasonable walking distance even for households outside of the study area. Larger vegetation-covered areas are located in the very downstream part of the subarea. However, these are not publicly accessible, so this part of the subarea has a deficit of public green space. At least two smaller parks ( $<0.5$ ha) are available in this area.

In the IND-MIDDLE subarea, public green spaces are also concentrated in a single part. The area surrounding the Quebrada Aries tributary is well served, while the western part of the subarea lacks accessible green spaces and parks. There are smaller parks in the Free Trade Zone outside the industrial area, but they do not have good accessibility nor an area $>0.5$ ha. Provided that residents cross the northern boundary of the subarea, the Ruta 3 expressway, three other green areas from the URBAN-MIDDLE subarea are accessible.

The accessibility of public green spaces in the URBAN-MIDDLE subarea also shows deficits. Not all inhabitants have access to a public green space $>0.5$ ha within $300 \mathrm{~m}$ of their place of residence. While the accessibility to public green spaces south of the Burío River is good, there is a lack of parks and green spaces in (i) the western part of the subarea, (ii) in the city centre of Heredia, (iii) north of the coffee plantation, and (iv) in the district of Mercedes. Although the 700-m buffer of 13.4 ha of green space at the Brava-Heredia border extends across much of the northern URBAN-MIDDLE subarea, this portion almost entirely lacks residential public green space (distance $>300$, size 0.5-10 ha). Approximately half of the green space in the subarea is located along the two watercourses. In particular, the estuary and lower reaches of the Burío River are characterized by accessible green spaces. Furthermore, it is worth highlighting that there are 74 small parks in the subarea, with sizes ranging from $171 \mathrm{~m}^{2}$ to $4723 \mathrm{~m}^{2}$. More than half (45) are located south of the Burío River. In some cases, the small parks are also part of the larger public green spaces. The small parks mitigate the deficit of public green spaces in some places, but public green space 


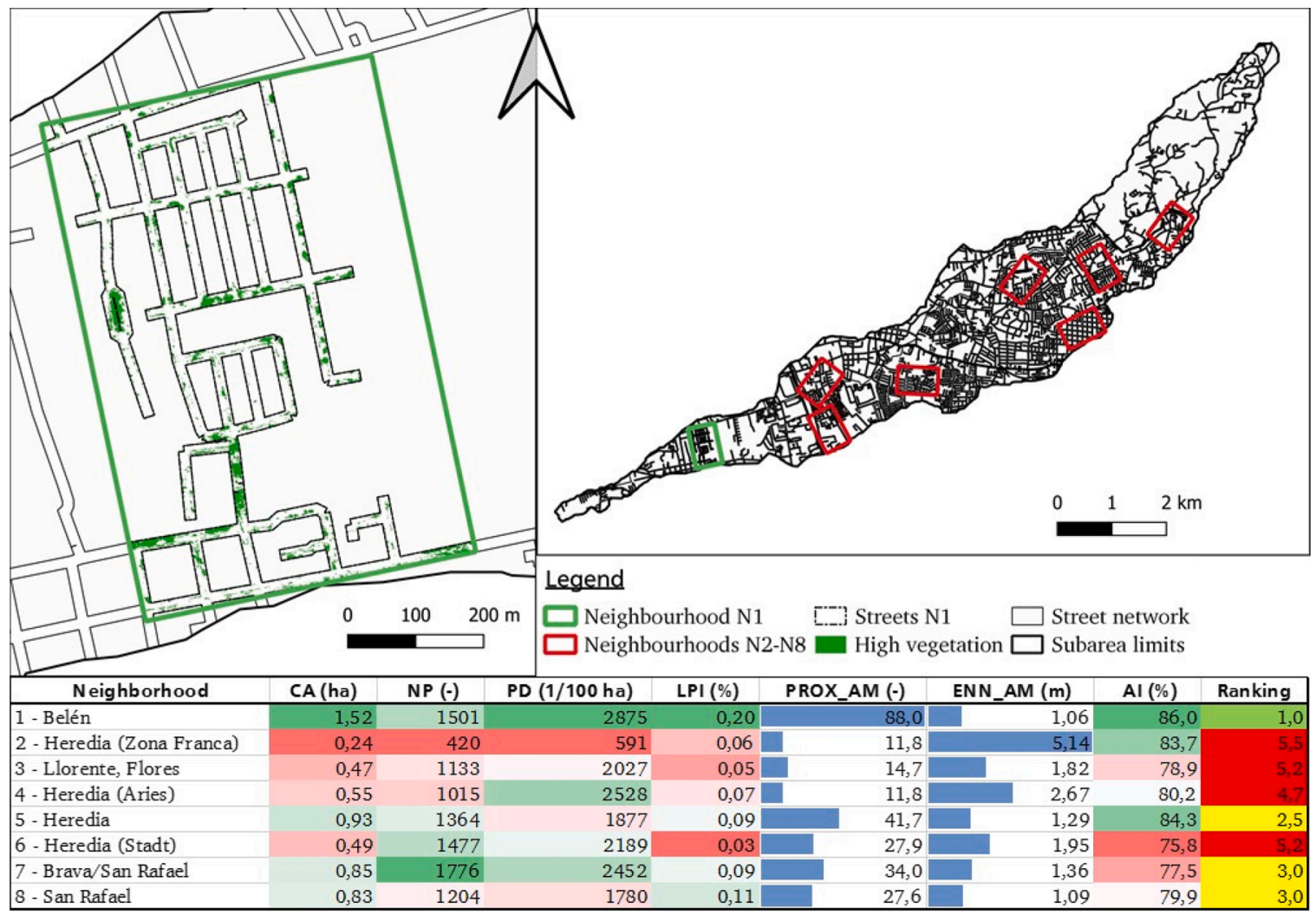

Fig. 7. Location of the 8 neighbourhoods (top right), example of street greenery classification of neighbourhood 1 (N1; top left), and calculated landscape metrics for all neighbourhood (table at the bottom).

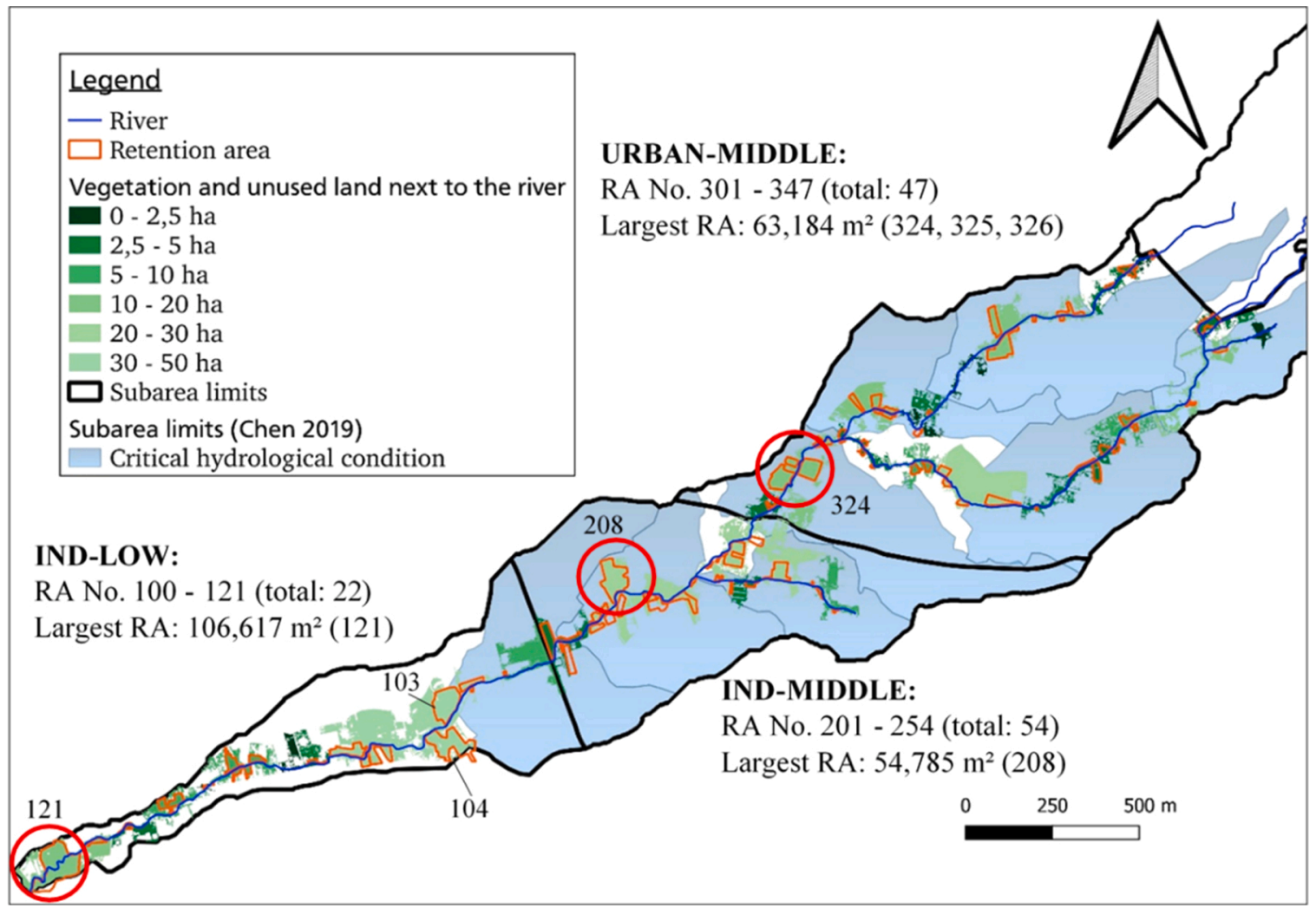

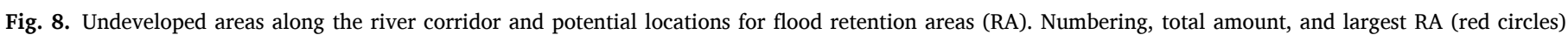
indicated for each subarea (For interpretation of the references to colour in this figure legend, the reader is referred to the web version of this article). 
Table 4

Potential for new green infrastructures in the different subareas.

\begin{tabular}{lll}
\hline Subarea & GI potential & $\begin{array}{l}\text { Area } \\
\text { (ha) }\end{array}$ \\
\hline & $\begin{array}{l}\text { Public green } \\
\text { space }\end{array}$ & 33.3 \\
& $\begin{array}{l}\text { Retention area } \\
\text { Industrial-urban lower reach (IND-LOW) in Alajuela }\end{array}$ & 33.5 \\
and Belén & Green roofs & 18.4 \\
& Permeable & 3.4 \\
& pavement & $\mathbf{8 8 . 7}$ \\
& Total & 24.6 \\
& Public green & space \\
Industrial-urban middle reach (IND-MIDDLE) in & Retention area & 23.4 \\
Flores and Heredia & Green roofs & 19.4 \\
& Permeable & 21.4 \\
& pavement & $\mathbf{8 8 . 8}$ \\
& Total & 19.7 \\
Highly urbanized middle reach (URBAN-MIDDLE) in & Public green & space \\
Heredia, Flores, Brava and San Rafael & Greention area & 28.4 \\
& Permeable & 2.0 \\
& pavement & 2.5 \\
& Total & $\mathbf{5 2 . 6}$ \\
\hline
\end{tabular}

areas per inhabitant are still well below the WHO (2016) recommendations of $10 \mathrm{~m}^{2} / \mathrm{hab}$. (Table 3 ). The forests and green spaces of the RURAL subarea have a positive impact on the northern part of the subarea. In this area, a green space $>10$ ha is also available to the population at a distance $<700 \mathrm{~m}$.

Only within the cantons of San Rafael and Brava and a small part of Heredia are the criteria of having a 0.5 ha green area close to housing $(<$ $300 \mathrm{~m})$ and a 10 ha green area close to settlement $(<700 \mathrm{~m})$ met. These deficits are also reflected in the public green area per inhabitant ratios summarized in Table 3.

\subsection{Neighbourhood scale}

The analysed neighbourhoods have different settlement structures and vary in their amount of street greenery and their shares of sealed surfaces (Table 3). $5.1 \%$ (N8 - San Rafael) up to $17.5 \%$ (N6 - Heredia) of the 37 ha of the neighbourhoods are sealed. Fig. 7 shows the selected neighbourhoods and the results of the FRAGSTATS calculation of the high vegetation within the street space. Street trees cover between 0.24 ha (N2 - Zona Franca) and 1.52 ha (N1 - Belén) of the neighbourhoods' surface. Larger green patches (LPI), like an alley with several trees lined up, are only found in N1. The square street-neighbourhood in Heredia (N6) has the smallest contiguous areas of high vegetation, only single trees are detected. The area-weight distance (ENN_AM) between trees varies between $1.06 \mathrm{~m}-2.67 \mathrm{~m}$ in most neighbourhoods and is especially high in the free trade zone $(5.14 \mathrm{~m}, \mathrm{~N} 2)$. The results show that the roads are almost entirely used for motorised traffic, and are not used multifunctionally. In the four neighbourhoods N2, N3, N4 and N6, the ratio of "high vegetation" to "sealed surface" is below 1:10. In N1 and N5, respectively, this ratio is $3.5: 10$ and 2:10.

\subsection{Object scale}

More than one-third of the area in the three urban subareas is occupied by pavement and buildings (Fig. 3). There is 631 ha classified as buildings in the entire area. However, as potential sites for green infrastructure in the form of green roof implementation only larger industrial and commercial buildings were considered. 20 larger supermarkets with roof areas between $199 \mathrm{~m}^{2}$ and $7280 \mathrm{~m}^{2}$ were identified within the entire watershed (total roof area: $40,307 \mathrm{~m}^{2}$ ). Few other dispersed buildings that are potentially suitable for green roofs were also identified. Particularly large buildings were found in the IND-LOW and
IND-MIDDLE subareas. Here, the buildings of the Free Trade Zone America as well as other industrial warehouses and office buildings have a total roof area of $478,988 \mathrm{~m}^{2}$. There is also a larger hotel $\left(10,341 \mathrm{~m}^{2}\right)$ in the IND-LOW. However, not all roofs are appropriate for green roofs conversion. Some of the roofs are already occupied by photovoltaics, helipads, and cooling systems (America Free Zone, 2021).

Fig. 8 shows undeveloped areas along the river corridor and potential locations for flood retention basins. The watercourse itself, riparian areas, vegetation directly adjacent to the watercourse, and undeveloped land have a total area of 309 ha in the three urban subareas. This corresponds to an area share of $14-29 \%$ in the three subareas. However, of the total 309 ha, only 85.3 ha are suitable for conversion into retention basins or floodplains. Vacant land, existing parks, and agricultural land are particularly identified. Areas with only dense cover by tall vegetation were not considered as potential retention areas, as retention basins here are only possible by clearing several trees. Other areas are to be preferred. The vegetation area of the coffee plantation was not considered because a large-scale conversion was assumed to be infeasible.

The sub-basins highlighted in blue in Fig. 8 show the areas that were assessed as critical for flood generation in a hydrologic analysis of the watershed (Chen et al., 2021). The assessment was based on rainfall-runoff modelling of a ten-year return period rainfall event. Flooding has occurred at several subbasin outfalls. As can be seen in Fig. 8, there are only a few larger suitable areas in some of these critical areas. Urban development along the watercourse is often highly dense there. Therefore, it is important to achieve a runoff-reducing effect by implementing several retention areas along the river corridor.

The identified retention areas along the watercourse correspond to $0.5-3.9 \%$ of the areas to be drained and increase in size in a downstream direction. The potential for retention areas is very low in the URBANMIDDLE subarea. Few retention areas are available along the watercourse relative to the area to be drained $(<1.5 \%)$. The large areas 103, 104, and 121 (Fig. 8) increase the retention potential downstream.

\subsection{Recommendations for Green Infrastructure conservation and improvement}

Some of the green spaces and GI in the watershed can be upgraded multifunctionally. Furthermore, there is the possibility to introduce new GI elements at identified potential sites. The theoretical potential is high due to the diverse GI placement possibilities. For larger-scale GI elements such as retention basins, infiltration basins, or constructed wetlands, potential areas are available in the three urban subareas that were classified as bare soil (11\%) or low vegetation (19.6\%). On-site analyses showed that GI can also be implemented on a small scale and along streets and pavements in residential neighbourhoods within the study area (Fluhrer et al., 2021). There is also potential to expand GI in the watershed at a larger scale. Table 4 lists the potential areas of the different GI elements for each subarea. A total of 152.5 ha were identified for the implementation of various GI elements and 77.6 ha for conversion into public green spaces.

In parts of the urbanized watershed with a lack of green spaces accessibility, 11 areas ( $>1$ ha) for potential public green space development were identified. The transformation of these open spaces into parks would significantly improve the level of accessibility in the different cantons (Fig. 6). If all areas identified as suitable were used, the coverage rate would increase (i) from $7.7 \mathrm{~m}^{2} / \mathrm{hab}$. to $18.6 \mathrm{~m}^{2} / \mathrm{hab}$. in canton of Belén, (ii) from 3.2 to $11.2 \mathrm{~m}^{2} /$ hab. in Flores and (iii) from 7.4 to $10.8 \mathrm{~m}^{2} /$ hab., in Heredia. However, the deficit of public green spaces in the squarely laid out streets in Heredia (city centre) cannot be remedied. The area has no unused areas larger than 0.5 ha. Only a 2883 $\mathrm{m}^{2}$ area of unused land could be identified.

Different recommendations were developed based on the existing settlement structures. While in the subarea URBAN-MIDDLE only a change in the street space could bring a multifunctional upgrading. In contrast, in IND-LOW and IND-MIDDLE the potential is higher since 


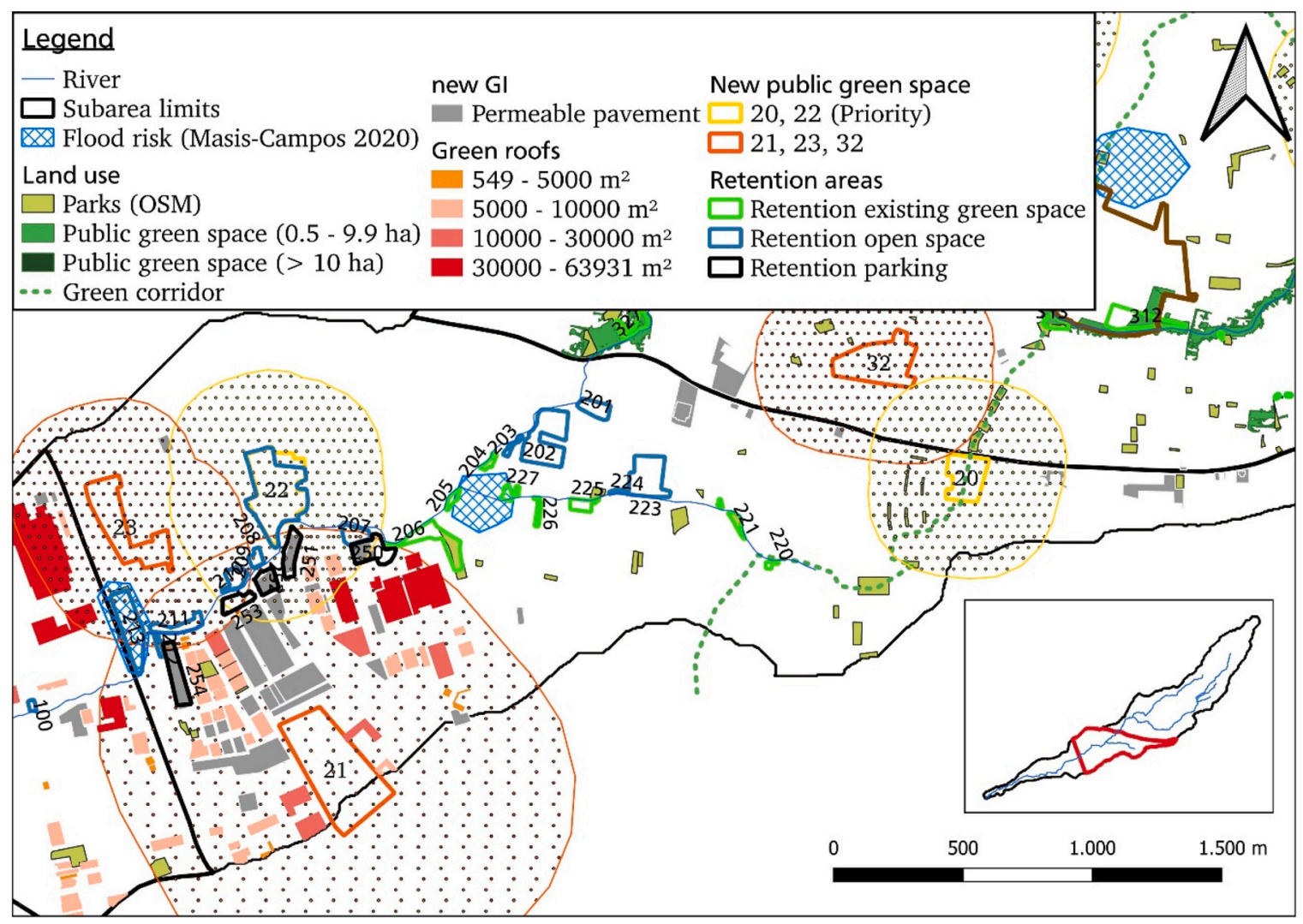

Fig. 9. Detailed recommendations for GI improvement for subarea IND-MIDDLE.

parking areas, parks, and open spaces could be improved with different GI elements.

Fig. 9 shows the subarea IND-MIDDLE and recommendations for GI implementation in detail (see Fig. A1 for recommendations for IND-LOW and Fig. A2 for URBAN-MIDDLE in the Annex). A total of 95 potential flood retention areas (RA) were identified across the watershed. Of these 95 areas, 32 are located in existing public green spaces. Given the high competition for space, for a greater multifunctional improvement, the RA in existing public green spaces should be considered first (RA within existing green spaces: 104, 108, 109, 204-206, 220-227, 309-315, 318-321, 327, 334-339, 347; marked in green in Figs. 9, A1 and A2 of Annex A). Multifunctional enhancement of these green spaces could be achieved through the implementation of retention and infiltration basins.

New public green spaces should be provided with GI. The proposed new public parks 10 (with RA 103), 12 (with RA 121) and 22 (with RA 208) could be planned and implemented in a multifunctional manner (Fig. A1 in Annex A). The largest increase in social functions could be achieved within proposed areas 20, 22, 34 and 35 (Fig. 6). This would lead to a significant increase in the accessibility of public green spaces for a large part of the population who are located in areas that currently have no public parks within $300 \mathrm{~m}$ from their housing.

In the IND-LOW subarea, determining the feasibility of the larger RA 103, 108 and 116 should be prioritised (Fig. A1 in Annex A). In the estuary area to the Pirro River, the approx. 10 ha large RA 12 could potentially be used as flood retention area. This area is also suitable for conversion into a public park.

When implementing flood retention basins, preference should be given to areas most affected by flooding. Fig. 9 as well as Figs. A1 and A2 (Annex A) show both potential GI areas and areas with higher levels of flood risk (Masís-Campos et al., 2020). At the Quebrada Aries tributary in the IND-MIDDLE, Masís-Campos et al. (2020) found frequent flooding in the channelised estuary. Due to dense development, land scarcity is particularly pronounced. RA 225, 226 and 227 are located here in an existing green space (Fig. 10). In multifunctional upgrading, the above-mentioned areas should be preferentially considered. In order to be able to control the flood risk in the area of the Ruta 1 motorway, the large parking lots of the free trade zone (RA 250-254, Fig. 10) should be examined with regard to temporary use as flooding areas. A combination of green and grey infrastructure is recommended at this site. This could mitigate the peak runoff of an intense rainfall event through temporary storage.

Within the URBAN-MIDDLE subarea (Fig. A2 in Annex A), RA 316, $317,319-321,340,341$ and 347 should be considered with priority for GI implementation. In addition, during extreme rainfall and runoff events, two larger agricultural areas along the watercourse are potentially available as floodplains.

No vacant land was determined in the western part of the watershed in the town of Heredia. Given this, determining the potential for GI implementation with the road space in this area through on-site analysis is recommended. Fig. A2 in Annex A shows examples of streets that could be suitable for extensive greening with filter strips and street trees (indicated as street greenery in Fig. A2 in the Annex). Larger GI elements could only be implemented here if the traffic routing was changed and the use of some streets by motorised traffic would be restricted to gain space for street greenery. Furthermore, a green corridor is proposed in Fig. A2 in annex as well as several small parks and larger vegetation areas are proposed to form a corridor, marked by stepping stone habitats. It is recommended that the green spaces in this area are preserved and the ecological corridor protected.

The large agricultural areas in the watershed should continue to be managed in order to maintain the regulating and providing ecosystem services of these green areas. The forests in the northern subarea (RURAL) should also be preserved and protected. Due to their size, they contribute particularly strongly to urban biodiversity (Cvejić et al., 2015). 


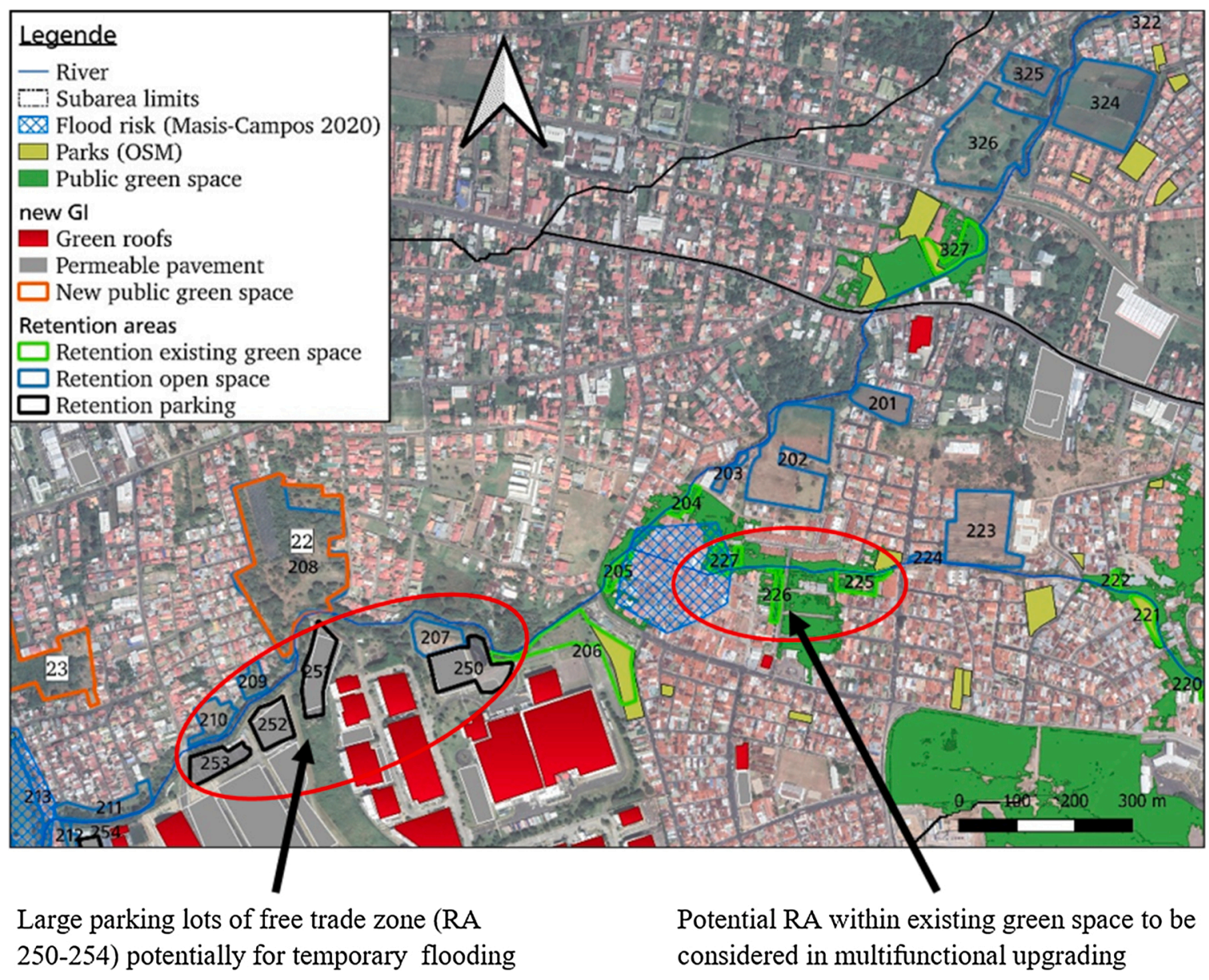

Fig. 10. Detail of a parts of subareas IND-MIDDLE and URBAN-MIDDLE showing recommendations for GI implementation.

\section{Discussion}

The methodology presented and applied in this study enables the assessment of existing green infrastructure at multiple scales. It is based on freely available data and software, thus I can be applied to any other place as well when being contextually aware. The detailed description of the methodology and use of data and software as well as the showcasing with a particular application serve as practical guidance for its replication. For the particular context of the case study, a watershed with different subareas including the river corridor, the neighbourhood, and the object scales was chosen. These scales were considered relevant to assess the characteristics and problem context of the area - a highly urbanized watershed with flooding problems and lacking green space but also to generate recommendations for increasing the efficacy of existing GI and spatial configuration of land use.

For applications of the methodology in other areas, other spatial scales may be more suitable. For instance, if surface water flow related issues are not relevant, scales relating to important administrative boundaries or city limits may be chosen in place of the watershed. The use of neighbourhoods and their street networks as the next lower scale is justified for both urbanized areas and when street greenery is prevalent. This enables the assessment of the potential for green infrastructure in public space of built-up areas and is particularly suited when considering the potential for small scale GI elements. The object scale in this study was chosen because it enables the association of elements of the urban fabric with specific GI types such as flat roofed buildings as sites for green roof implementation or parking space for permeable pavements.

Besides the identification of different GI types, the multiple scale approach also enables the assessment of different functions. The focus of this study was on recreational functions (indicator: accessibility), ecological functions (indicator: landscape metrics and area related functions reported in other studies), and flood mitigating functions (indicator: suitability of sites for implementation). These functions are only a few of potential GI functions and the respective indicators were selected based on the study area context and the data availability. This kind of assessment provides an overview and can be applied in the same manner for other study areas, but the identified GI functions and suitability of sites for GI development have to be verified i.e., validated through detailed studies and field work. The detailed planning of GI is out of the scope of this study. Besides the GI functions considered in this study, there are many other social and ecological functions that GI can provide. Some functions like health benefits can to a certain degree be considered as derivatives of functions that were considered in this study (e.g., recreation or flood mitigation), others like the regulation of temperature or air quality as well as noise reduction are additional ones. Especially the function of temperature regulation of GI is becoming increasingly important in the context of adaptation strategies to climate change.

The quality of the results of this study directly depends on the data and information used. The high-resolution land use classification based on true colour satellite imagery provides detailed information regarding the spatial distribution of different land uses and represents the basis for the identification, characterization, and calculation of GI, potential functions, and implementation sites. It enables the identification of small-scale objects such as individual trees and street greenery, but it is not free of error. Since the classification is based on pixel colours, misclassifications can occur, for instance when green buildings or street elements such as painted roofs or cars are confused with vegetation. Misclassifications require thorough post-processing to increase the 
accuracy of the classification. The land use classification of this study had an overall accuracy of $89 \%$, which is within the range of other classifications using true colour satellite imagery (Chapa et al., 2019). The images selected for this study were of high quality and depict the landscape uniformly.

For the analysis of other study areas, however, care should always be taken to ensure that the satellite images depict the landscape evenly. Clouds, different colour rendition or turbidity of the images affect the land use classification. Furthermore, care should be taken that the images composing the area of study were taken at the same time of year. Particularly in the case of analyses in countries with a pronounced dry period, the land cover with low vegetation changes considerably during the course of the year. However, other freely available satellite imagery that enables a better classification of vegetation, e.g., multi-spectral images with spectral bands to calculate NDVI (Normalized Difference Vegetation Index), have a much lower spatial resolution and are not suitable to detect small-scale objects. The quality of the satellite images is important. Additional information, e.g., whether a green space represents a public park providing a recreational function or buildings potentially suitable for permeable pavements were retrieved from OSM. The use of this information contributed to a better validation of certain GI functions and potentials.

Post-processing improves the land use classification, but it can also introduce further uncertainties. Line shape files from OSM were used to define the road network and overlaid with the land use classification. For simplicity, line shape files were uniformly buffered on both sides, giving all roads in the watershed the same width. This does not correspond to reality and leads to errors in land use classification. Multi-lane roads are often represented by multiple lines in OSM, mitigating errors caused by the uniform road widths. Nevertheless, for wide roads, the asphalted pavements are incorrectly assigned to classes buildings or bare soil; for narrow streets, there is an overlay of buildings by the buffered streets. The error due to the varying road widths is estimated to be smaller than the misclassification due to the confusion of the class sealing with other land use classes.

Other characteristics and functions of the existing GI were assessed based on the landscape metrics calculated with FRAGSTATS using the LUC. Hence, the landscape metrics are subject to the same error as the LUC itself. Furthermore, there is an ongoing discussion about the meaning and interpretation of the landscape and connectivity metrics (Guo et al., 2018; Kindlmann and Burel, 2008; Kupfer, 2012; Zhang et al., 2019) as used in this study. A general problem is the standardization of landscape metrics. The landscape metrics of this study are difficult to compare with other studies, as they also depend on the input parameters, such as resolution and study area size (Lustig et al., 2015). Additionally, few comparable studies of small urban river basins exist as most studies using FRAGSTATS in urban areas were conducted on a larger scale. There is a need for further research in this area. However, a comparison of results in relative terms between the subareas of the watershed is possible and differences can be seen in the heterogeneous landscape of the watershed.

The quality of the LUC and the sieving of pixels also influence the landscape metrics. Misclassifications and small patches, such as backyard greenery, affect the calculations of the aggregation metrics. A landscape with one large green space and many scattered misclassifications of isolated pixels may be evaluated as more interconnected than a landscape with several high-quality green spaces between which no isolated green pixels are found. This problem is another potential limitation of the validity of the landscape metrics. However, since the metrics of the individual subareas are based on a LUC of comparable accuracy, the values of the entire landscape are subject to error. It is assumed that disturbances of misclassifications and isolated pixel groups occur equally in all sub-areas and thus the comparability of the parameters is given despite uncertainties.

The subareas of the middle reaches are the most fragmented and have the highest degree of surface sealing. But landscape connectivity should be improved in all urbanised parts of the study area. For a more precise assessment of connectivity and identification of ecologically valuable corridors, the area could be further analysed with graph-based landscape metrics. For more detailed recommendations on biodiversity protection, the functional connectivity of the landscape should also be determined, which necessitates a more detailed knowledge of native flora and fauna. The coverage of green spaces per inhabitant is poor and there is a lack of even and comprehensive distribution of public green spaces. It should be noted that the actual accessibility of parks in the watershed may be overestimated by the analysis carried out. When considering public green spaces using remote sensing methods, the assessment of accessibility is subject to a high level of uncertainty. Information from the map service providers OSM and Google Maps facilitates the classification into publicly accessible and private or commercially operated green spaces. Nevertheless, uncertainty remains in the selection of green spaces. The quality of the green spaces cannot be described in detail using the available satellite images. For a reliable assessment of green spaces, for example using the criteria of Voigt et al. (2014), an on-site investigation is necessary. In this study, the green spaces of at least 0.5 ha in the LUC were categorised as public, if a public park marker was available in OSM. This resulted in the whole area classified in the LUC being considered in the next steps. However, the accessible green space is possibly smaller than the area marked out for the further analysis steps.

In the cantons of Belén, Flores and Heredia, only 3.2-7.7 $\mathrm{m}^{2} /$ per hab. are available. These values are very low and well below the WHO (2016) recommendations. They are consistent with the low values of other surveys in the San José area of the GAM (Municipalidad de Curridabat, 2019). The values for Heredia Canton in the watershed are higher than the coverage rate $\left(2.7 \mathrm{~m}^{2} /\right.$ per hab.) of Heredia City determined by Morales Cerdas et al. (2018). To assess the actual accessibility, quality, and recreational potential of the green spaces, the areas identified in this work should be analysed in more depth through an on-site survey. In line with the participatory approach of the GI, it is proposed to involve the population in the assessment of the existing urban green structure(s) and those to be developed. The participation of residents can help to determine the user requirements for public parks and to take safety aspects into account. Following the participatory identification of flood risk areas by Masís-Campos et al. (2020), a crowd mapping of the strengths and weaknesses of the urban green can complement the analysis of the public green spaces.

To confirm the validity of the GI analysis of the street networks at the neighbourhood scale, an on-site analysis of the considered streetscapes should be carried out. In some cases, considerable differences were found between the different neighbourhoods. There are also differences between the neighbourhoods.

Recent findings highlight the importance to consider the different spatial scales where benefits are perceived with regard to different policy levels (Badiu et al., 2016; Davies and Lafortezza, 2017). GI is considered a key instrument for city management and policy making to achieve a more resilient and sustainable development (Capotorti et al., 2019; de Groot et al., 2010; Niemelä et al., 2010; Young and McPherson, 2013). Integrative approaches are necessary to take advantage of the synergies occurring at different scales and societal objectives at the urban and regional level (Capotorti et al., 2019). This study contributes with its multi-scale and multi-function approach to consider more integrative approaches. We recommend linking this study's physical-spatial approach with actor and governance oriented approaches in future investigations.

\section{Conclusions}

The Quebrada Seca-Rio Burío watershed in Costa Rica experiences frequent heavy rainfall and flooding. As in many other metropolitan areas, climate change and urbanisation processes intensify this hydrologic characteristic of the region. The use of freely available spatial data 
enables a land cover classification of high spatial resolution and thereby the identification of the spatial distribution of existing GI and potential sites for new GI elements at the watershed, neighbourhood, and object level. The calculation of landscape metrics based on the results of the land cover classification has proven helpful to reveal a quite heterogeneous functionality of the existing GI at the different spatial scales. Thus, the specific potential and deficits of different subareas of the larger watershed, among street networks of different characteristics and particular sites such as larger buildings, parking lots, or retention areas within the river corridor, could be identified. The results of this study show that due to the scarcity of unoccupied land in the study area, the concept of green infrastructure is a promising means for effectively enhancing the urban landscape in a multifunctional way. The communication and visualization of spatially explicit recommendations for GI preservation and improvement measures was possible based on these results. These recommendations are of a screening character at the landscape level as they are exclusively based on remote sensing information and the identified GI and potentials for improvement need to be validated through site visits and field investigations. However, the benefit of this assessment is that it is relatively low-cost and less time consuming when compared to field work.

The developed methodology can be used to assess even different aspects of GI which can be determined based on land cover information and land use metrics. It is not limited to the GI functions nor the types of new GI elements considered in this study. By using free and open-access data and software, the method can be used worldwide and is particularly suitable for evaluating multifunctional GI in urban areas and countries, especially in the Global South. In other parts of the world, other data sources (e.g., high resolution LUC, planning documents, green space inventories, etc.) may be available providing an even better basis for the application of the methodology presented in this study. Such studies can substantially contribute to more sustainable city development and can address challenges related to prevailing urbanization challenges.

\section{Data availability}

Raw data and other supplementary material are available at the following repository: osf.io/7zpcj.

No data was used for the research described in the article.

Data will be made available on request.

\section{Author statement}

All persons who meet authorship criteria are listed as authors and all authors certify that they have participated sufficiently in the work to take public responsibility for the content, including participation in the concept, design, analysis, writing, or revision of the manuscript. Furthermore, each author certifies that this manuscript has not be submitted to or published in any other journal before.

\section{Authorship contributions}

Conceptualization, N.A. and J.H.; funding acquisition, J.H.; investigation, N.A. and J.H.; methodology, N.A. and J.H.; supervision, J.H.; validation, N.A. and J.H.; visualization, N.A.; writing original draft, N. A.; writing review and editing, N.A. and J.H.

\section{Declaration of Competing Interest}

The authors declare that they have no known competing financial interests or personal relationships that could have appeared to influence the work reported in this paper.

\section{Acknowledgement}

We acknowledge the funding that we received from the German
Federal Ministry of Research and Education (Grant ID: 01UU1704).

\section{Annex A}

Table A1

Functions of different GI types, methods used for their determination and recommendations for multifunctional improvement.

\begin{tabular}{|c|c|c|c|}
\hline Function & GI type & $\begin{array}{l}\text { Determination } \\
\text { method and criteria }\end{array}$ & $\begin{array}{l}\text { Recommendation to } \\
\text { improve GI and multi- } \\
\text { functionality }\end{array}$ \\
\hline Ecological & $\begin{array}{l}\text { Vegetation } \\
\text { patches }\end{array}$ & $\begin{array}{l}\text { Land use classification } \\
\text { and landscape } \\
\text { metrics: Vegetated } \\
\text { areas }>1 \text { ha }\end{array}$ & $\begin{array}{l}\text { Conservation of } \\
\text { particular ecological } \\
\text { functions: patches of } \\
4.4-10 \text { ha as potential } \\
\text { habitats for urban } \\
\text { adapters, patches of } \\
10-27 \text { ha for } \mathrm{CO}_{2} \\
\text { storage, patches of } \\
27-53 \text { ha to sustain } \\
\text { urban biodiversity, and } \\
\text { patches > } 53 \text { ha as } \\
\text { habitat for urban } \\
\text { avoider species }\end{array}$ \\
\hline Ecological & $\begin{array}{l}\text { Green } \\
\text { corridors and } \\
\text { street } \\
\text { greenery }\end{array}$ & $\begin{array}{l}\text { Land use classification } \\
\text { and landscape } \\
\text { metrics: High } \\
\text { vegetation patches } \\
\text { within street networks } \\
\text { of different } \\
\text { neighbourhoods }\end{array}$ & $\begin{array}{l}\text { Prioritisation of } \\
\text { corridor increasing } \\
\text { connectivity, street } \\
\text { networks with ratios of } \\
\text { high vegetation to } \\
\text { sealed surface }<1: 10\end{array}$ \\
\hline Recreational & $\begin{array}{l}\text { Vegetation } \\
\text { patches }\end{array}$ & $\begin{array}{l}\text { Land use } \\
\text { classification, } \\
\text { landscape metrics, } \\
\text { and OSM: Vegetation } \\
\text { patches of low } \\
\text { convolution (patch } \\
\text { level metric FRACT < } \\
1,6),>0.5 \text { ha within } \\
300 \mathrm{~m} \text { of buildings } \\
\text { and }>10 \text { ha within } \\
700 \mathrm{~m} \text { of buildings } \\
\text { identified as public } \\
\text { green spaces }\end{array}$ & $\begin{array}{l}\text { Establishment of } \\
\text { additional parks where } \\
\text { accessibility is } \\
\text { insufficient (absence of } \\
\text { public parks within } 700 \\
\text { m distance) }\end{array}$ \\
\hline $\begin{array}{l}\text { Runoff } \\
\text { reduction }\end{array}$ & $\begin{array}{l}\text { Roof tops of } \\
\text { buildings }\end{array}$ & $\begin{array}{l}\text { Land use classification } \\
\text { and OSM: Large, flat- } \\
\text { roofed commercial } \\
\text { and industrial } \\
\text { buildings, larger } \\
\text { hotels, and } \\
\text { supermarkets }\end{array}$ & $\begin{array}{l}\text { Conversion to green } \\
\text { roofs }\end{array}$ \\
\hline $\begin{array}{l}\text { Runoff } \\
\text { reduction }\end{array}$ & $\begin{array}{l}\text { Large } \\
\text { parking lots }\end{array}$ & $\begin{array}{l}\text { Land use classification } \\
\text { and OSM: commercial } \\
\text { and industrial parking } \\
\text { lots in }>300 \mathrm{~m} \\
\text { distance from the } \\
\text { river }\end{array}$ & $\begin{array}{l}\text { Conversion to } \\
\text { permeable pavement }\end{array}$ \\
\hline $\begin{array}{l}\text { Flood } \\
\text { retention }\end{array}$ & $\begin{array}{l}\text { Large } \\
\text { parking lots }\end{array}$ & $\begin{array}{l}\text { Land use classification } \\
\text { and OSM: commercial } \\
\text { and industrial parking } \\
\text { lots in }<300 \mathrm{~m} \\
\text { distance from the } \\
\text { river }\end{array}$ & $\begin{array}{l}\text { Use for temporal flood } \\
\text { retention }\end{array}$ \\
\hline $\begin{array}{l}\text { Flood } \\
\text { retention }\end{array}$ & $\begin{array}{l}300 \mathrm{~m} \text { wide } \\
\text { river corridor }\end{array}$ & $\begin{array}{l}\text { Merged undeveloped } \\
\text { areas of bare soil, low, } \\
\text { and high vegetation } \\
(<10 \%) \text {. }\end{array}$ & $\begin{array}{l}\text { Prioritisation of largest } \\
\text { areas with critical } \\
\text { location within the } \\
\text { watershed (flood } \\
\text { prone), multifunctional } \\
\text { use of existing green } \\
\text { spaces or } \\
\text { multifunctional } \\
\text { development as public } \\
\text { parks. }\end{array}$ \\
\hline
\end{tabular}




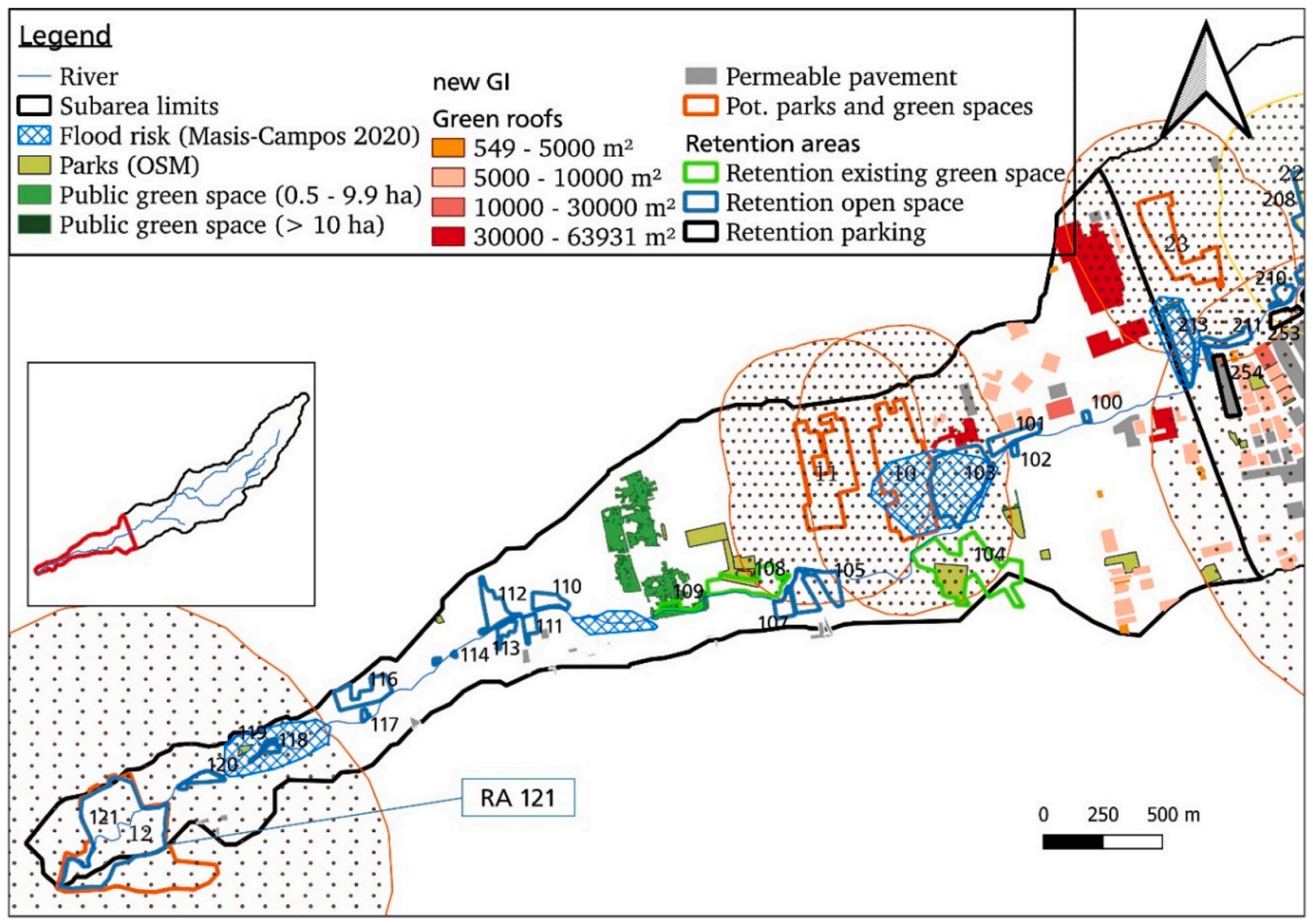

Fig. A1. Detailed recommendations for GI improvement for subarea IND-LOW.

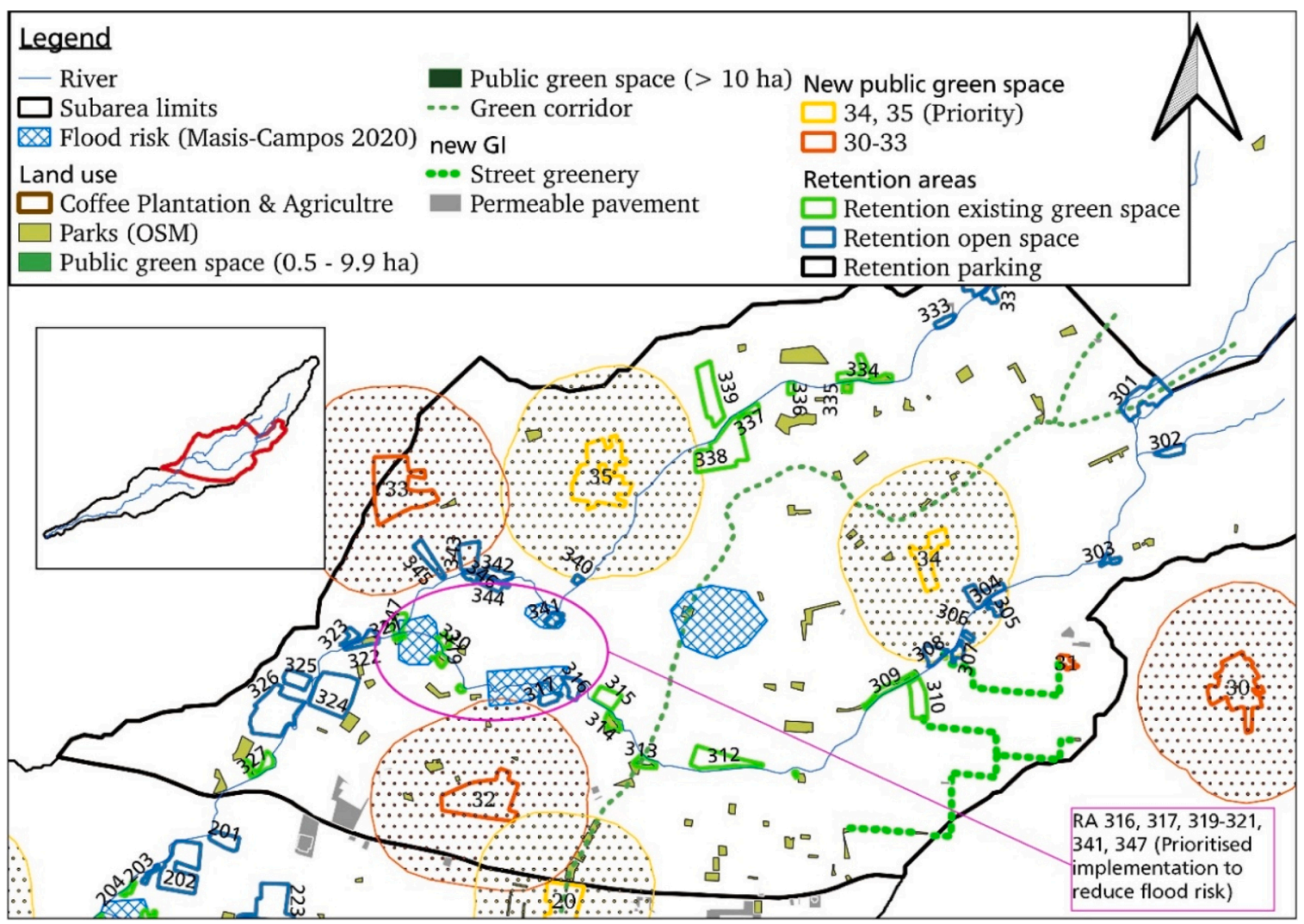

Fig. A2. Detailed recommendations for GI improvement for subarea URBAN-MIDDLE. 


\section{References}

Ahern, J., 2007. Green infrastructure for cities: the spatial dimension. In: Novotny, V., Brown, P. (Eds.), Cities of the Future: Towards Integrated Sustainable Water and Landscape Management. IWA Publishing. https://doi.org/10.2166/ 9781780405308.

Albert, C., Hack, J., Schmidt, S., Schröter, B., 2021. Planning and governing nature-based solutions in river landscapes: concepts, cases, and insights. Ambio. https://doi.org/ 10.1007/s13280-021-01569-z.

Allmapsoft, 2021. Google Maps. Downloader [WWW Document]. Offline Map Mak. URL http://www.allmapsoft.com/gmd/index.html (accessed 5.20.21).

America Free Zone, 2021. WEB-VirtualTour-AFZ [WWW Document]. URL. http s://americafreezone.com/TourVirtualAFZ/.

Badiu, D.L., Iojă, C.I., Pătroescu, M., Breuste, J., Artmann, M., Niță, M.R., Grădinaru, S. R., Hossu, C.A., Onose, D.A., 2016. Is urban green space per capita a valuable target to achieve cities' sustainability goals? Romania as a case study. Ecol. Indic. 70, 53-66. https://doi.org/10.1016/j.ecolind.2016.05.044.

Bartesaghi Koc, C., Osmond, P., Peters, A., 2018. Evaluating the cooling effects of green infrastructure: a systematic review of methods, indicators and data sources. Sol. Energy 166, 486-508. https://doi.org/10.1016/j.solener.2018.03.008.

Beninde, J., Veith, M., Hochkirch, A., 2015. Biodiversity in cities needs space: a metaanalysis of factors determining intra-urban biodiversity variation. Ecol. Lett. 18, 581-592. https://doi.org/10.1111/ele.12427.

Capotorti, G., Alós Ortí, M.M., Copiz, R., Fusaro, L., Mollo, B., Salvatori, E., Zavattero, L., 2019. Biodiversity and ecosystem services in urban green infrastructure planning: a case study from the metropolitan area of Rome (Italy). Urban For. Urban Green. 37, 87-96. https://doi.org/10.1016/j.ufug.2017.12.014.

Chan, F.K.S., Griffiths, J.A., Higgitt, D., Xu, S., Zhu, F., Tang, Y.-T., Xu, Y., Thorne, C.R., 2018. "Sponge City" in China-a breakthrough of planning and flood risk management in the urban context. Land Use Policy 76, 772-778. https://doi.org/ 10.1016/j.landusepol.2018.03.005.

Chapa, F., Hariharan, S., Hack, J., 2019. A new approach to high-resolution urban land use classification using open access software and true color satellite images. Sustainability 11, 5266. https://doi.org/10.3390/su11195266.

Chapa, F., Krauss, M., Hack, J., 2020. A multi-parameter method to quantify the potential of roof rainwater harvesting at regional levels in areas with limited rainfall data. Resour. Conserv. Recycl. 161 https://doi.org/10.1016/j resconrec.2020.104959.

Chen, V., Bonilla Brenes, J.R., Chapa, F., Hack, J., 2021. Development and modelling of realistic retrofitted Nature-based Solution scenarios to reduce flood occurrence at the catchment scale. Ambio. https://doi.org/10.1007/s13280-020-01493-8.

Congredo, L., 2020. Semi-Automatic Classification Plugin Documentation. https://doi. org/10.13140/RG.2.2.25480.65286/1.

Cvejić, R., Eler, K., Pintar, M., Železnikar, Š., Haase, D., Kabisch, N., Strohbach, M., 2015 A Typology of Urban Green Spaces, Ecosystem Services Provisioning Services and Demands. Copenhagen.

Davies, C., Lafortezza, R., 2017. Urban green infrastructure in Europe: Is greenspace planning and policy compliant? Land Use Policy 69, 93-101. https://doi.org/ 10.1016/j.landusepol.2017.08.018.

de Groot, R.S., Alkemade, R., Braat, L., Hein, L., Willemen, L., 2010. Challenges in integrating the concept of ecosystem services and values in landscape planning, management and decision making. Ecol. Complex. 7, 260-272. https://doi.org/ 10.1016/j.ecocom.2009.10.006.

Dhakal, K.P., Chevalier, L.R., 2017. Managing urban stormwater for urban sustainability: barriers and policy solutions for green infrastructure application. J. Environ. Manage. 203, 171-181. https://doi.org/10.1016/j.jenvman.2017.07.065.

Dobbs, C., Escobedo, F.J., Clerici, N., de la Barrera, F., Eleuterio, A.A., MacGregorFors, I., Reyes-Paecke, S., Vásquez, A., Zea Camaño, J.D., Hernández, H.J., 2019. Urban ecosystem Services in Latin America: mismatch between global concepts and regional realities? Urban Ecosyst. 22, 173-187. https://doi.org/10.1007/s11252018-0805-3.

EPA, 2021. What Is Green Infrastructure? Webpage Green Infrastruct. Progr. United States Environmetal Prot. Agency [WWW Document]. URL https://www.epa.gov/ green-infrastructure/what-green-infrastructure (accessed 12.10.21).

European Commission, 2013. Communication from the Commission to the European Parliament, the Council, the European Economic and Social Committee and the Committee of the Regions: Green Infrastructure (GI) — Enhancing Europe's Natural Capital. Brussels, Belgium.

Fletcher, T.D., Shuster, W., Hunt, W.F., Ashley, R., Butler, D., Arthur, S., Trowsdale, S., Barraud, S., Semadeni-Davies, A., Bertrand-Krajewski, J.-L., Mikkelsen, P.S. Rivard, G., Uhl, M., Dagenais, D., Viklander, M., 2015. SUDS, LID, BMPs, WSUD and more - the evolution and application of terminology surrounding urban drainage. Urban Water J. 12, 525-542. https://doi.org/10.1080/1573062X.2014.916314.

Fluhrer, T., Chapa, F., Hack, J., 2021. A methodology for assessing the implementation potential for retrofitted and multifunctional urban green infrastructure in public areas of the global south. Sustainability 13, 384. https://doi.org/10.3390/ su13010384.

Gill, S.E., Handley, J.F., Ennos, A.R., Pauleit, S., 2007. Adapting cities for climate change: the role of the green infrastructure. Built Environ. 33, 115-133.

Gorelick, N., Hancher, M., Dixon, M., Ilyushchenko, S., Thau, D., Moore, R., 2017. Google earth engine: planetary-scale geospatial analysis for everyone. Remote Sens. Environ. 202, 18-27. https://doi.org/10.1016/j.rse.2017.06.031.

Grafius, D.R., Corstanje, R., Harris, J.A., 2018. Linking ecosystem services, urban form and green space configuration using multivariate landscape metric analysis. Landsc. Ecol. 33, 557-573. https://doi.org/10.1007/s10980-018-0618-z.
Grunewald, K., Richter, B., Meinel, G., Herold, H., Syrbe, R.U., 2016. Vorschlag bundesweiter indikatoren zur erreichbarkeit öffentlicher grünflächen: Bewertung der Ökosystemleistung „Erholung in der stadt”. Naturschutz und Landschaftsplan. 48, 218-226.

Guo, S., Saito, K., Yin, W., Su, C., 2018. Landscape connectivity as a tool in green space evaluation and optimization of the Haidan District, Beijing. Sustainability 10, 1979. https://doi.org/10.3390/su10061979.

Hack, J., Schröter, B., 2021. Nature-based solutions for River restoration in metropolitan areas. In: Bears, R. (Ed.), The Palgrave Encyclopedia OfUrban and Regional Futures. Palgrave Macmillan, Cham, pp. 1-10. https://doi.org/10.1007/978-3-030-51812-7_ 166-1.

Hack, J., Molewijk, D., Beißler, M.R., 2020. A conceptual approach to modeling the geospatial impact of typical urban threats on the habitat quality of river corridors. Remote Sens. (Basel) 12, 1345. https://doi.org/10.3390/rs12081345.

Handley, J., Pauleit, S., Slinn, P., Lindley, S., Baker, M., Barber, A., Jones, C., 2003. Providing Accessible Natural Greenspace in Towns and Cities: a Practical Guide to Assessing the Resource and Implementing Local Standards for Provision. Manchester.

Kim, H.W., Park, Y., 2016. Urban green infrastructure and local flooding: the impact of landscape patterns on peak runoff in four Texas MSAs. Appl. Geogr. 77, 72-81. https://doi.org/10.1016/j.apgeog.2016.10.008.

Kindlmann, P., Burel, F., 2008. Connectivity measures: a review. Landsc. Ecol. https:// doi.org/10.1007/s10980-008-9245-4.

Kupfer, J.A., 2012. Landscape ecology and biogeography. Prog. Phys. Geogr. Earth Environ. 36, 400-420. https://doi.org/10.1177/0309133312439594.

Lustig, A., Stouffer, D.B., Roigé, M., Worner, S.P., 2015. Towards more predictable and consistent landscape metrics across spatial scales. Ecol. Indic. 57, 11-21. https://doi. org/10.1016/j.ecolind.2015.03.042.

Malarvizhi, K., Kumar, S.V., Porchelvan, P., 2016. Use of high resolution google earth satellite imagery in landuse map preparation for urban related applications. Procedia Technol. 24, 1835-1842. https://doi.org/10.1016/j.protcy.2016.05.231.

Margulis, S., 2016. Vulnerabilidad y adaptación de las ciudades de América Latina al cambio climático. Santiago de Chile.

Masís-Campos, R., Vargas Picado, H., 2014. Incremento de áreas impermeables por cambios de usos de la tierra en la microcuenca del río Burío. Rev. Reflexiones 93. https://doi.org/10.15517/rr.v93i1.13742.

Masís-Campos, R., Avendaño-Flores, I., Reyes-Chaves, J., 2020. Cartografía del perfil socioeconómico y de viviendaen la microcuenca Río Burío Quebrada Seca. InterSedes 21, 175-209. https://doi.org/10.15517/isucr.v21i43.41991.

McGarigal, K., Cushman, S.A., Ene, E., 2012. FRAGSTATS v4: Spatial Pattern Analysis Program for Categorical and Continuous Maps.

Meerow, S., Newell, J.P., 2017. Spatial planning for multifunctional green infrastructure: growing resilience in Detroit. Landsc. Urban Plan. 159, 62-75. https://doi.org/ 10.1016/j.landurbplan.2016.10.005.

Morales Cerdas, V., Piedra Castro, L., Romero Vargas, M., Bermúdez Rojas, T., 2018. Indicadores ambientales de áreas verdes urbanas para la gestión en dos ciudades costarricenses. Rev. Biol. Trop. 66, 1421. https://doi.org/10.15517/rbt. v66i4.32258.

Municipalidad de Curridabat, 2019. Evaluación de la infraestructura verde y conectividad ecológica en el cantón de Curridabat. Curridabat.

Niemelä, J., Saarela, S.-R., Söderman, T., Kopperoinen, L., Yli-Pelkonen, V., Väre, S., Kotze, D.J., 2010. Using the ecosystem services approach for better planning and conservation of urban green spaces: a Finland case study. Biodivers. Conserv. 19, 3225-3243. https://doi.org/10.1007/s10531-010-9888-8.

Oreamuno, R., Villalobos, R., 2015. Estudios hidrológicos e hidráulicos en la cuenca Quebrada Seca Río-Burío. San José, Costa Rica.

Pérez Rubi, M., Hack, J., 2021. Co-design of experimental nature-based solutions for decentralized dry-weather runoff treatment retrofitted in a densely urbanized area in Central America. Ambio. https://doi.org/10.1007/s13280-020-01457-y.

QGIS Project, 2018. QGIS User Guide [WWW Document]. URL https://docs.qgis.org/2. 18/pdf/en/QGIS-2.18-UserGuide-en.pdf (accessed 5.20.21).

Quesada-Román, A., Villalobos-Portilla, E., Campos-Durán, D., 2021. Hydrometeorological disasters in urban areas of Costa rica, Central America. Environ. Hazards 20, 264-278. https://doi.org/10.1080/17477891.2020.1791034.

Reyes Päcke, S., Figueroa Aldunce, I.M., 2010. Distribución, superficie y accesibilidad de las áreas verdes en Santiago de Chile. EURE 36, 89-110. https://doi.org/10.4067/ S0250-71612010000300004.

Roy, A.H., Wenger, S.J., Fletcher, T.D., Walsh, C.J., Ladson, A.R., Shuster, W.D., Thurston, H.W., Brown, R.R., 2008. Impediments and solutions to sustainable, watershed-scale urban stormwater management: lessons from Australia and the United States. Environ. Manage. 42, 344-359. https://doi.org/10.1007/s00267-0089119-1.

Schwarz, N., Moretti, M., Bugalho, M.N., Davies, Z.G., Haase, D., Hack, J., Hof, A., Melero, Y., Pett, T.J., Knapp, S., 2017. Understanding biodiversity-ecosystem service relationships in urban areas: a comprehensive literature review. Ecosyst. Serv. 27, 161-171. https://doi.org/10.1016/j.ecoser.2017.08.014.

Singh, A., Sarma, A.K., Hack, J., 2020. Cost-effective optimization of nature-based solutions for reducing urban floods considering limited space availability. Environ. Sci. Process. Impacts 7. https://doi.org/10.1007/s40710-019-00420-8.

Spanowicz, A.G., Jaeger, J.A.G., 2019. Measuring landscape connectivity: on the importance of within-patch connectivity. Landsc. Ecol. 34, 2261-2278. https://doi. org/10.1007/s10980-019-00881-0.

Taubenböck, H., Wurm, M., Esch, T., Dech, S. (Eds.), 2015. Globale Urbanisierung. Springer, Berlin Heidelberg, Berlin, Heidelberg. https://doi.org/10.1007/978-3662-44841-0. 
Towsif Khan, S., Chapa, F., Hack, J., 2020. Highly resolved rainfall-runoff simulation of retrofitted green stormwater infrastructure at the micro-watershed scale. Land 9 , 339. https://doi.org/10.3390/land9090339.

Tran, T.D.-B., Puissant, A., Badariotti, D., Weber, C., 2011. Optimizing spatial resolution of imagery for urban form detection - the cases of France and Vietnam. Remote Sens. (Basel) 3, 2128-2147. https://doi.org/10.3390/rs3102128.

Turner, M.G., 1989. Landscape ecology: the effect of pattern on process. Annu. Rev. Ecol. Syst. 20, 171-197. https://doi.org/10.1146/annurev.es.20.110189.001131.

United Nations, 2019. World Urbanization Prospects - the 2018 Revision. New York.

Van Oijstaeijen, W., Van Passel, S., Cools, J., 2020. Urban green infrastructure: a review on valuation toolkits from an urban planning perspective. J. Environ. Manage. 267, 110603 https://doi.org/10.1016/j.jenvman.2020.110603.

Vásquez, A., Devoto, C., Giannotti, E., Velásquez, P., 2016. Green infrastructure systems facing fragmented cities in Latin America - case of Santiago, Chile. Procedia Eng. 161, 1410-1416. https://doi.org/10.1016/j.proeng.2016.08.602.

Vásquez, A., Giannotti, E., Galdámez, E., Velásquez, P., Devoto, C., 2019. Green infrastructure planning to tackle climate change in Latin American cities. In: Henríquez, C., Romero, H. (Eds.), Urban Climates in Latin America. Springer
International Publishing, Cham, pp. 329-354. https://doi.org/10.1007/978-3-31997013-4_13.

Voigt, A., Kabisch, N., Wurster, D., Haase, D., Breuste, J., 2014. Structural diversity: a multi-dimensional approach to assess recreational services in Urban Parks. Ambio 43, 480-491. https://doi.org/10.1007/s13280-014-0508-9.

WHO Regional Office for Europe, 2016. Urban Green Spaces and Health - a Review of Evidence. Copenhagen, Denmark.

Wright Wendel, H.E., Zarger, R.K., Mihelcic, J.R., 2012. Accessibility and usability: green space preferences, perceptions, and barriers in a rapidly urbanizing city in Latin America. Landsc. Urban Plan. 107, 272-282. https://doi.org/10.1016/j. landurbplan.2012.06.003.

Young, R.F., McPherson, E.G., 2013. Governing metropolitan green infrastructure in the United States. Landsc. Urban Plan. 109, 67-75. https://doi.org/10.1016/j. landurbplan.2012.09.004.

Zhang, Z., Meerow, S., Newell, J.P., Lindquist, M., 2019. Enhancing landscape connectivity through multifunctional green infrastructure corridor modeling and design. Urban For. Urban Green. 38, 305-317. https://doi.org/10.1016/j. ufug.2018.10.014. 